\title{
Electrochemical In Situ pH Control Enables Chemical-Free Full Urine Nitrification With Concomitant Nitrate Extraction
}

Jolien De Paepe ${ }^{a, b, c}$, Peter Clauwaert ${ }^{a, c}$, Maria Celeste Gritti ${ }^{a}$, Ramon Ganigué ${ }^{a, c}$, Benedikt Sas ${ }^{d}$, Siegfried E. Vlaeminck ${ }^{\mathrm{c}, \mathrm{e}, \#}$ and Korneel Rabaey ${ }^{\mathrm{a}, \mathrm{c}, \#^{*}}$

\# equally contributed as senior authors

${ }^{a}$ Center for Microbial Ecology and Technology (CMET), Department of Biotechnology, Faculty of Bioscience Engineering - Ghent University, Coupure Links 653, 9000 Gent, Belgium

b Departament d'Enginyeria Química, Biològica I Ambiental, Escola d'Enginyeria - Universitat Autònoma de Barcelona, Bellaterra 08193 Barcelona, Spain

c Center for Advanced Process Technology and Urban Resource Efficiency (CAPTURE, www.capture-resources.be)

d Department of Food Quality and Food Safety, Faculty of Bioscience Engineering - Ghent University, Coupure links 653, 9000 Gent, Belgium

e Research Group of Sustainable Energy, Air and Water Technology, Department of Bioscience Engineering - University of Antwerp, Groenenborgerlaan 171, 2020 Antwerpen, Belgium

* Corresponding author: Korneel.Rabaey@UGent.be;

The supporting information contains 40 pages including 16 figures and 16 tables. 


\section{A. Experimental setup and operation}

\section{A1. Experimental setup}

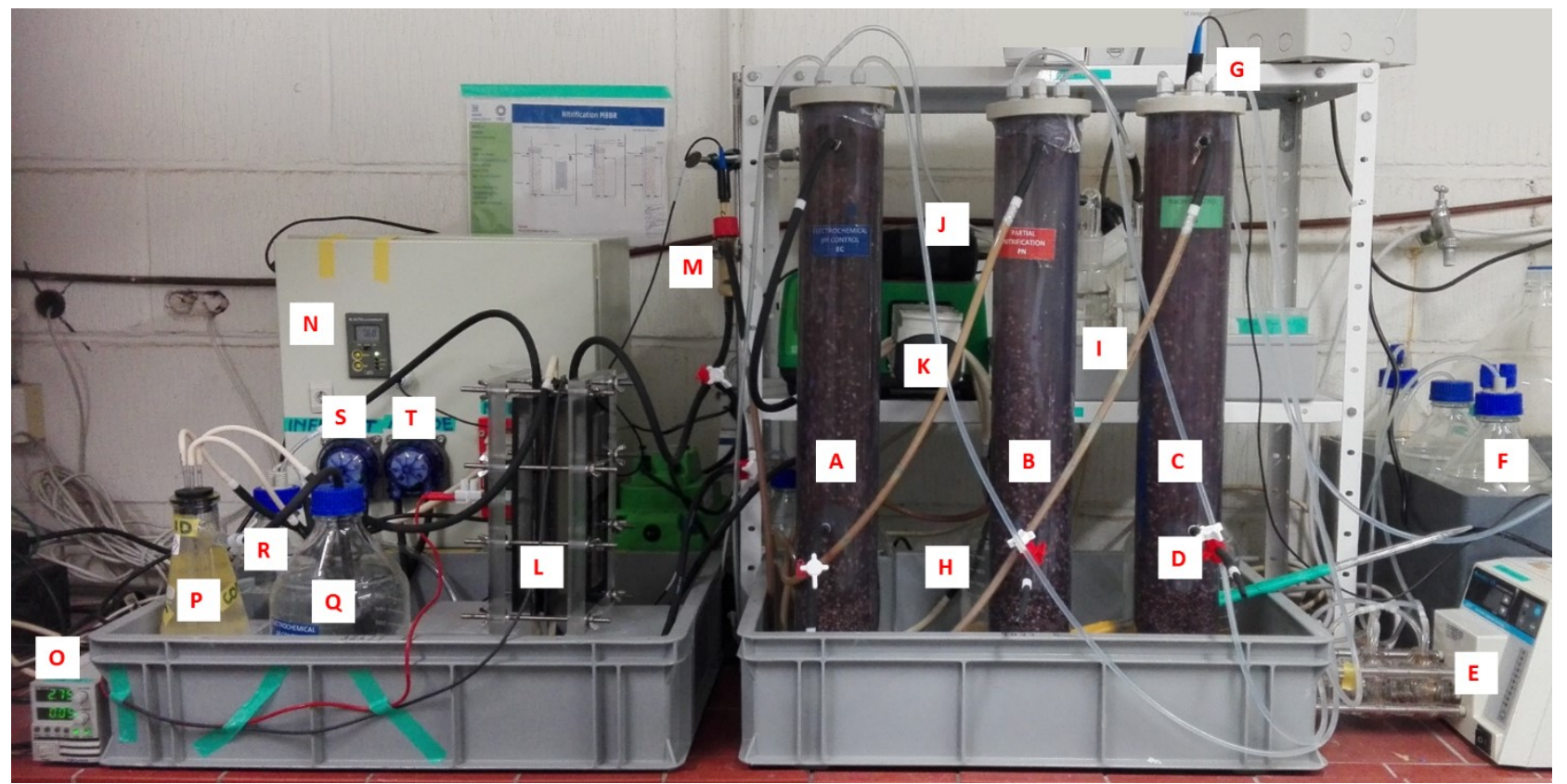

Figure S1. Experimental setup.

A: full nitrification reactor with electrochemical hydroxide addition

$\mathrm{B}$ : partial nitrification reactor without $\mathrm{pH}$ control

C: full nitrification reactor with $\mathrm{NaOH}$ addition

D: sampling port

E: influent pump (Masterflex $\AA L / S \circledR$, Cole-Parmer $\AA, U S A)$

$F$ : influent bottles

$\mathrm{G}: \mathrm{pH}$ electrode

$\mathrm{H}$ : effluent bottle

I: gas washing bottle (to humidify the air)

J: air pump (Air pump 400, Eheim, Germany)

K: recirculation pump (Watson Marlow 520, USA)

$\mathrm{L}$ : electrochemical cell

$\mathrm{M}$ : $\mathrm{pH}$ electrode

$\mathrm{N}$ : control unit

O: digital-control power supply ( $Z+$ series, TDK lambda, Japan)

$\mathrm{P}$ : recirculation bottle of the middle compartment

Q: effluent bottle of the middle compartment

$R$ : recirculation bottle of the anodic compartment

S: influent pump of the middle compartment

$\mathrm{T}$ : recirculation pump of the anodic compartment 


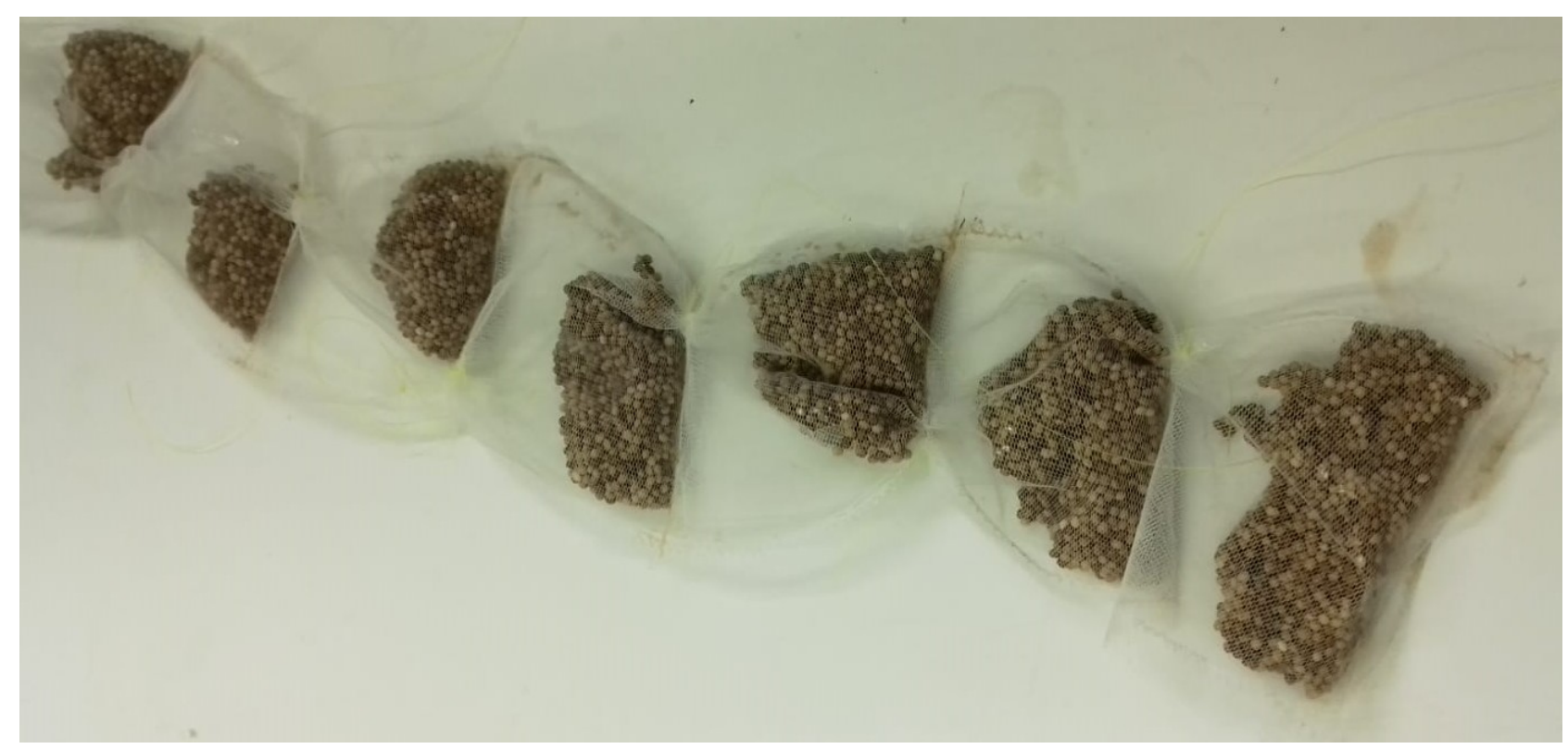

Figure S2. Bags with polyvinyl alcohol (PVA) beads. Each MBBR was filled with polyvinyl alcohol (PVA) beads (Kuraray Aqua Co, Ltd., Tokyo, Japan), contained in bags made from fine fishnet material and kept in suspension by the aeration and liquid recirculation. The bags prevented the beads from entering the recirculation loop and from clogging/covering the aeration stones. 


\section{A2. Control system to adapt the current of the power supply based on the $\mathrm{pH}$ in the bioreactor}

The electrochemical cell was galvanostatically controlled at a current density between 0 and $20 \mathrm{~A}$ $\mathrm{m}^{-2}$ depending on the $\mathrm{pH}$ at the outlet of the cathodic compartment using a control system programmed in LabVIEW. When the $\mathrm{pH}$ was low, a relatively high current was applied in order to increase the $\mathrm{pH}$, whereas a high $\mathrm{pH}$ resulted in a lower applied current. As an example (Figure S3), in configuration 1 , a pH below 7.4 resulted in a current of $0.15 \mathrm{~A}$. When the $\mathrm{pH}$ was between 7.4 and 7.6, a current of $0.1 \mathrm{~A}$ was applied. $\mathrm{A} \mathrm{pH}$ between 7.6 and 7.8 resulted in a current of $0.05 \mathrm{~A}$. When the $\mathrm{pH}$ was above 7.8 , the voltage was fixed at $2 \mathrm{~V}$ (no current). This allowed to control the $\mathrm{pH}$ relatively stably at $\sim 7.5$.

The $\mathrm{pH}$ values and corresponding current values were altered for the different configurations and/or operational phases. For instance, configuration 1 was tested at two different $\mathrm{pH}$ set points: 7.5 and 6.5. Due to the concentration in the middle compartmnent in configuration 2 and 3 (and thus a higher proton concentration), a higher current was needed in order to compensate for the increased diffusion of protons towards the cathodic compartment.
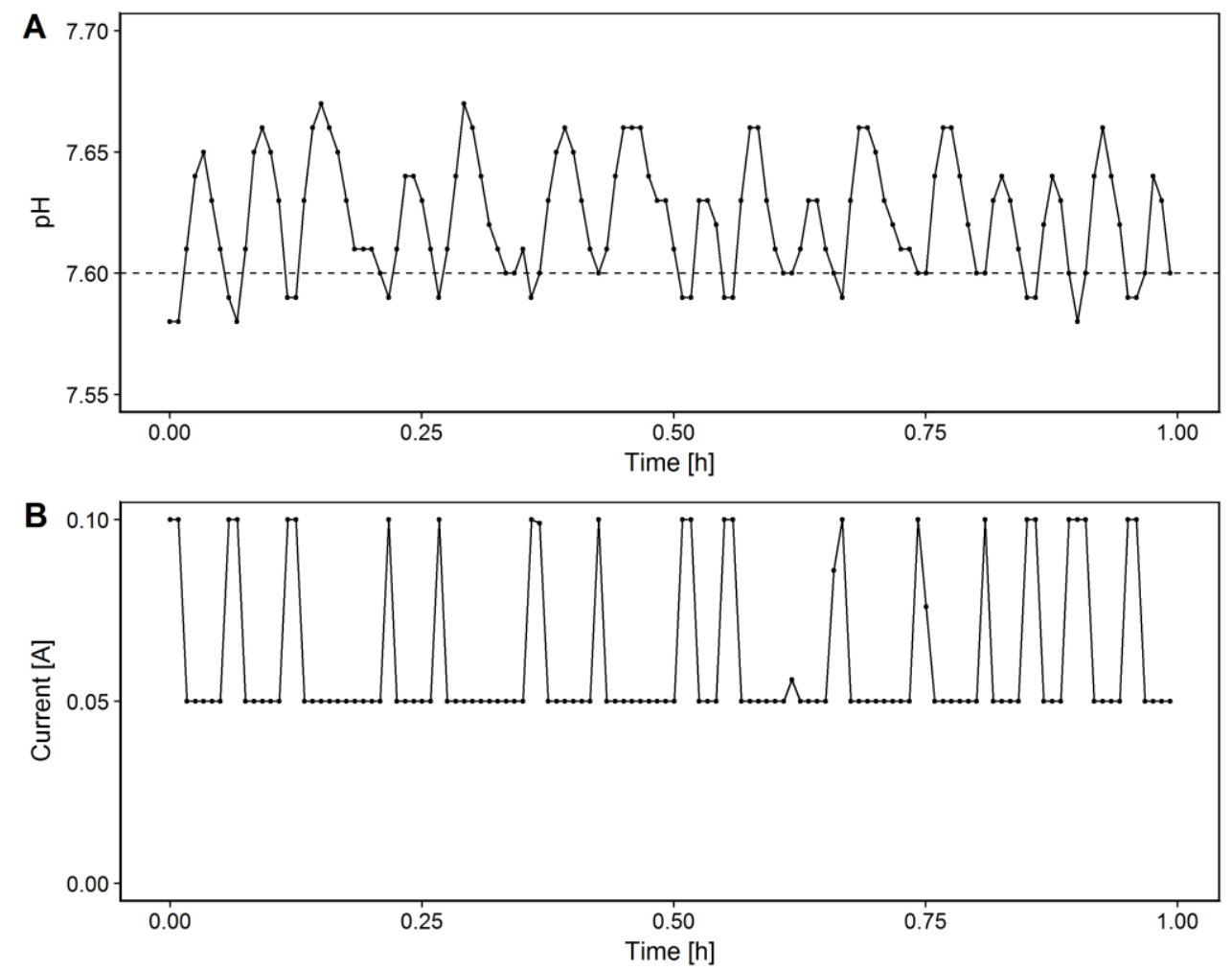

Figure S3. Full nitrification reactor with electrochemical hydroxide addition: $\mathrm{pH}$ and current profile over 1 hour (in configuration 1, pH set point of 7.5). When the $\mathrm{pH}$ was between 7.4 and 7.6, a current of $0.1 \mathrm{~A}$ was applied. $\mathrm{A} \mathrm{pH}$ between 7.6 and 7.8 resulted in a current of $0.05 \mathrm{~A}$. 


\section{A3. Reactor inoculation and start-up}

Polyvinyl alcohol beads, previously used for urine nitrification ${ }^{1}$, were reactivated in aerated vessels receiving spikes of a buffered ammonium sulfate solution after storage for more than one year at $4^{\circ} \mathrm{C}$. Subsequently, the beads were transferred into the MBBRs and an additional $250 \mathrm{~mL}$ of nitrifying inoculum (ABIL, Avecom, Belgium) was added ( $0.19 \mathrm{~g} \mathrm{VSS} \mathrm{L}^{-1}$ with an activity of $0.4 \mathrm{~g} \mathrm{TAN} \mathrm{g}^{-1}$ VSS $\mathrm{d}^{-1}$, as indicated by the provider). After inoculation, the MBBRs were operated for 7 days in fed-batch mode (to allow for additional biofilm formation on the beads) and for 33 days in continuous mode on a buffered synthetic ammonium sulfate solution with a stepwise increasing $\mathrm{N}$ concentration (50-360 $\left.\mathrm{mg} \mathrm{N} \mathrm{L}^{-1}\right)$. After 40 days, alkalinized urine $\left(1.75 \mathrm{~g} \mathrm{~N} \mathrm{~L}^{-1}\right)$ was dosed to the MBBR and the loading was gradually increased over a period of 30 days by increasing the influent flow rate from $0.2 \mathrm{~L} \mathrm{~d}^{-1}$ to $0.5 \mathrm{~L} \mathrm{~d}^{-1}$. 


\section{A4. Electrochemical urine alkalinization}

The MBBR with partial nitrificaiton and MBBR with electrochemical hydroxide addition were fed with electrochemically stabilized urine. The urine was alkalinized with a three chamber electrochemical cell (with AEM+CEM) according to De Paepe et al. (2020)². Briefly, a crystallizer was filled with 2-4L of diluted fresh urine $(33 \%)$ and the content was continuously recirculated over the cathodic compartment of the electrochemical cell. The electrochemical cell consisted of three compartments, made from Perspex® plates and frames, a stainless steel wire mesh (564 $\mu \mathrm{m}$ mesh width, $20 \times 5$ $\mathrm{cm}^{2}$, Solana, Belgium) as cathode and a dimensionally stable titanium anode coated with iridium oxide (Magneto Special Anodes, The Netherlands). The cathodic compartment was separated from the middle compartment by an anion exchange membrane (AEM, Ultrex AMI-7001, Membranes International Inc., NJ, USA), whereas the middle compartment and the anodic compartment were separated with a cation exchange membrane (CEM, Ultrex CMI-7000s, Membranes International Inc., NJ, USA). The anolyte and middle compartment solution initially consisted of $1 \mathrm{~L} 0.05 \mathrm{M}$ or $0.02 \mathrm{M}$ $\mathrm{Na}_{2} \mathrm{SO}_{4}$, respectively. The cell was galvanostatically controlled at a current density of 100 or $150 \mathrm{~A}$ $\mathrm{m}^{-2}$ (membrane projected surface) using a digital-control DC power supply (LABPS3005, Velleman, Belgium). On average, an electric charge of $\sim 2.8 \mathrm{kC} \mathrm{L}^{-1}$ was required to increase the $\mathrm{pH}$ to 12 . Once a $\mathrm{pH}$ of 12 was reached, the power supply was switched off and the stabilised urine was collected from the crystallizer, filtered over a porous fibre cloth to retain the precipitates, and stored at room temperature in closed vessels. Every $\sim 5$ stabilisation batches, the cathodic compartment was rinsed with the acidic middle compartment solution in order to remove scaling on the electrode, spacer and membrane.

Besides temporarily stabilizing the urine prior to nitrification, the electrochemical pre-treatment reduced the scaling potential (by precipitation of divalent cations with phosphate and sulfate) and the salinity of the urine (by migration of anions (mainly chloride) to the middle compartment). On average $88 \pm 7 \%$ of calcium, $91 \pm 6 \%$ of magnesium, $78 \pm 16 \%$ of phosphate, $64 \pm 14 \%$ of chloride and $58 \pm 18 \%$ of sulfate were removed from the urine by the electrochemical pre-treatment (Figure S4). The TAN (total ammonia nitrogen) concentration after electrochemical pre-treatment was about $18 \%$ lower than before treatment, indicating some ammonia volatilisation or ammonia diffusion to the middle compartment. The $\mathrm{N}$ loss was however limited as less than $5 \%$ of the total influent nitrogen was present as TAN. 

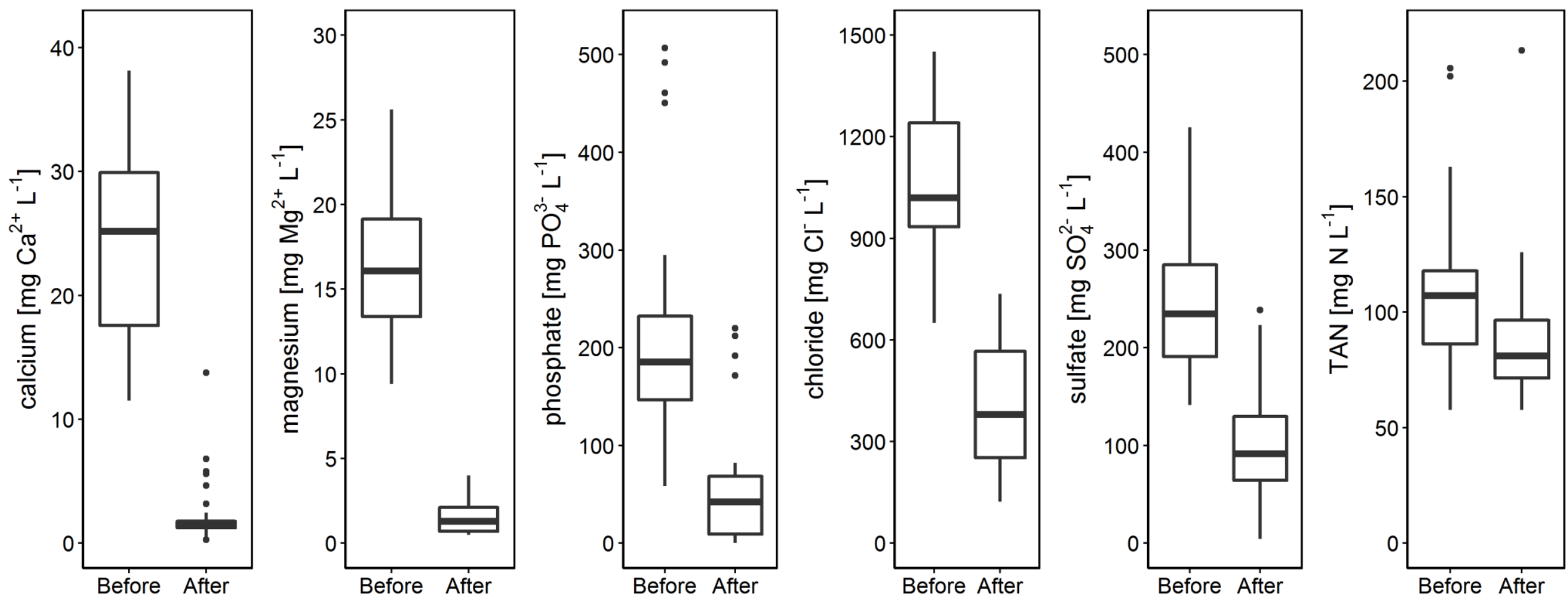

Figure S4. Calcium, magnesium, phosphate, chloride, sulfate and total ammonia nitrogen (TAN) concentration in diluted urine (33\%) before and after electrochemical pre-treatment $(n=32)$. 


\section{B. Full nitrification with electrochemical hydroxide addition}

\section{B1. Composition of influent, bioreactor effluent, middle compartment effluent and anodic compartment}

\section{effluent}

Table S1. Influent composition of the full nitrification reactor with electrochemical hydroxide addition.

\begin{tabular}{|c|c|c|c|c|c|c|c|c|c|c|c|c|c|c|c|c|c|c|c|c|c|c|}
\hline & & \multicolumn{6}{|c|}{ configuration 1} & \multicolumn{9}{|c|}{ configuration 2} & \multicolumn{6}{|c|}{ configuration 3} \\
\hline & & \multicolumn{3}{|c|}{ pH 7.5} & \multicolumn{3}{|c|}{ pH 6.5} & \multicolumn{3}{|c|}{ factor 2} & \multicolumn{3}{|c|}{ factor 5} & \multicolumn{3}{|c|}{ factor 2} & \multicolumn{3}{|c|}{ factor 2} & \multicolumn{3}{|c|}{ factor 5} \\
\hline number of samples & & \multicolumn{3}{|c|}{17} & \multicolumn{3}{|c|}{10} & \multicolumn{3}{|c|}{12} & \multicolumn{3}{|c|}{10} & \multicolumn{3}{|c|}{4} & \multicolumn{3}{|c|}{6} & \multicolumn{3}{|c|}{4} \\
\hline $\mathrm{pH}$ & & 11.8 & \pm & 0.3 & 11.1 & \pm & 0.5 & 11.2 & \pm & 0.5 & 10.7 & \pm & 1.0 & 11.9 & \pm & 0.2 & 11.4 & \pm & 0.1 & 11.3 & \pm & 0.1 \\
\hline electrical conductivity & {$\left[\mathrm{mS} \mathrm{cm}^{-1}\right]$} & 3.9 & \pm & 0.4 & 4.3 & \pm & 0.2 & 4.3 & \pm & 0.1 & 5.7 & \pm & 2.2 & 6.6 & \pm & 0.2 & 4.4 & \pm & 0.6 & 4.3 & \pm & 0.1 \\
\hline suspended COD & [mg COD L-1] & 1376 & \pm & 63 & 1304 & \pm & 78 & 1345 & \pm & 21 & 1351 & \pm & 514 & 1993 & \pm & 284 & 1697 & \pm & 170 & 1592 & \pm & 20 \\
\hline total nitrogen & [mg N L-1] & 1588 & \pm & 177 & 1453 & \pm & 65 & 1520 & \pm & 47 & 1548 & \pm & 81 & 1980 & \pm & 147 & 1597 & \pm & 154 & 1630 & \pm & 35 \\
\hline total ammonia nitrogen & [mg N L-1] & 60 & \pm & 7 & 60 & \pm & 6 & 58 & \pm & 3 & 242 & \pm & 484 & 64 & \pm & 8 & 59 & \pm & 6 & 57 & \pm & 2 \\
\hline nitrite & [mg N L-1] & 1 & \pm & 1 & 1 & \pm & 1 & 0 & \pm & 0 & 1 & \pm & 1 & 1 & \pm & 0 & 1 & \pm & 0 & 1 & \pm & 0 \\
\hline nitrate & [mg N L-1] & 4 & \pm & 2 & 2 & \pm & 1 & 3 & \pm & 1 & 2 & \pm & 3 & 3 & \pm & 0 & 3 & \pm & 0 & 2 & \pm & 0 \\
\hline phosphate & {$\left[\mathrm{mg} \mathrm{L}^{-1}\right]$} & 58 & \pm & 25 & 40 & \pm & 4 & 47 & \pm & 10 & 90 & \pm & 44 & 159 & \pm & 15 & 69 & \pm & 25 & 62 & \pm & 3 \\
\hline sulfate & {$\left[\mathrm{mg} \mathrm{L}^{-1}\right]$} & 144 & \pm & 18 & 132 & \pm & 5 & 137 & \pm & 16 & 160 & \pm & 13 & 210 & \pm & 56 & 152 & \pm & 13 & 150 & \pm & 5 \\
\hline chloride & {$\left[\mathrm{mg} \mathrm{L}^{-1}\right]$} & 581 & \pm & 66 & 586 & \pm & 13 & 563 & \pm & 49 & 638 & \pm & 131 & 828 & \pm & 23 & 546 & \pm & 59 & 518 & \pm & 11 \\
\hline sodium & {$\left[\mathrm{mg} \mathrm{L}^{-1}\right]$} & 574 & \pm & 27 & 573 & \pm & 49 & 553 & \pm & 9 & 602 & \pm & 53 & 799 & \pm & 12 & 532 & \pm & 94 & 496 & \pm & 20 \\
\hline potassium & {$\left[\mathrm{mg} \mathrm{L}^{-1}\right]$} & 550 & \pm & 27 & 563 & \pm & 54 & 545 & \pm & 7 & 576 & \pm & 18 & 672 & \pm & 16 & 497 & \pm & 79 & 477 & \pm & 19 \\
\hline
\end{tabular}


Table S2. Composition of the bioreactor liquid in the full nitrification reactor with electrochemical hydroxide addition.

\begin{tabular}{|c|c|c|c|c|c|c|c|c|c|c|c|c|c|c|c|c|c|c|c|c|c|c|}
\hline & & \multicolumn{6}{|c|}{ configuration 1} & \multicolumn{9}{|c|}{ configuration 2} & \multicolumn{6}{|c|}{ configuration 3} \\
\hline & & \multicolumn{3}{|c|}{ pH 7.5} & \multicolumn{3}{|c|}{ pH 6.5} & \multicolumn{3}{|c|}{ factor 2} & \multicolumn{3}{|c|}{ factor 5} & \multicolumn{3}{|c|}{ factor 2} & \multicolumn{3}{|c|}{ factor 2} & \multicolumn{3}{|c|}{ factor 5} \\
\hline \# samples & & \multicolumn{3}{|c|}{15} & \multicolumn{3}{|c|}{10} & \multicolumn{3}{|c|}{19} & \multicolumn{3}{|c|}{12} & \multicolumn{3}{|c|}{4} & \multicolumn{3}{|c|}{6} & \multicolumn{3}{|c|}{5} \\
\hline $\mathrm{pH}$ & & 7.6 & \pm & 0.1 & 6.5 & \pm & 0.3 & 7.3 & \pm & 0.3 & 7.6 & \pm & 0.2 & 7.4 & \pm & 0.1 & 7.4 & \pm & 0.1 & 7.1 & \pm & 0.3 \\
\hline electrical conductivity & {$\left[\mathrm{mS} \mathrm{cm}^{-1}\right]$} & 5.3 & \pm & 1.3 & 4.7 & \pm & 0.2 & 4.6 & \pm & 0.2 & 4.9 & \pm & 0.3 & 6.4 & \pm & 0.5 & 6.0 & \pm & 0.6 & 4.9 & \pm & 0.1 \\
\hline suspended COD & [mg COD L-1] & 180 & \pm & 39 & 122 & \pm & 8 & 114 & \pm & 13 & 113 & \pm & 49 & 110 & \pm & 16 & 132 & \pm & 18 & 108 & \pm & 4 \\
\hline total ammonia nitrogen & {$\left[\mathrm{mg} \mathrm{N} \mathrm{L}^{-1}\right]$} & 9 & \pm & 30 & 2 & \pm & 5 & 3 & \pm & 10 & 0 & \pm & 1 & 0 & \pm & 0 & 0 & \pm & 0 & 0 & \pm & 0 \\
\hline nitrite & [mg N L-1] & 5 & \pm & 13 & 0 & \pm & 0 & 2 & \pm & 1 & 12 & \pm & 35 & 1 & \pm & 0 & 3 & \pm & 5 & 2 & \pm & 1 \\
\hline nitrate & {$\left[\mathrm{mg} \mathrm{N} \mathrm{L}^{-1}\right]$} & 603 & \pm & 130 & 484 & \pm & 15 & 416 & \pm & 28 & 409 & \pm & 28 & 521 & \pm & 47 & 472 & \pm & 61 & 392 & \pm & 4 \\
\hline phosphate & {$\left[\mathrm{mg} \mathrm{L}^{-1}\right]$} & 51 & \pm & 24 & 52 & \pm & 3 & 61 & \pm & 48 & 57 & \pm & 20 & 120 & \pm & 15 & 120 & \pm & 30 & 50 & \pm & 5 \\
\hline sulfate & {$\left[\mathrm{mg} \mathrm{L}^{-1}\right]$} & 118 & \pm & 54 & 85 & \pm & 14 & 164 & \pm & 40 & 199 & \pm & 31 & 220 & \pm & 17 & 212 & \pm & 31 & 160 & \pm & 12 \\
\hline chloride & {$\left[\mathrm{mg} \mathrm{L}^{-1}\right]$} & 301 & \pm & 33 & 263 & \pm & 41 & 224 & \pm & 33 & 207 & \pm & 16 & 265 & \pm & 15 & 222 & \pm & 27 & 166 & \pm & 3 \\
\hline sodium & {$\left[\mathrm{mg} \mathrm{L}^{-1}\right]$} & 872 & \pm & 293 & 591 & \pm & 58 & 579 & \pm & 12 & 591 & \pm & 23 & 737 & \pm & 52 & 678 & \pm & 82 & 538 & \pm & 17 \\
\hline potassium & {$\left[\mathrm{mg} \mathrm{L}^{-1}\right]$} & 562 & \pm & 41 & 570 & \pm & 60 & 539 & \pm & 131 & 550 & \pm & 37 & 618 & \pm & 45 & 612 & \pm & 48 & 548 & \pm & 38 \\
\hline
\end{tabular}


Table S3. Composition of the middle compartment effluent of the full nitrification reactor with electrochemical hydroxide addition.

\begin{tabular}{|c|c|c|c|c|c|c|c|c|c|c|c|c|c|c|c|c|c|c|c|c|c|c|}
\hline & & \multicolumn{6}{|c|}{ configuration 1} & \multicolumn{9}{|c|}{ configuration 2} & \multicolumn{6}{|c|}{ configuration 3} \\
\hline & & \multicolumn{3}{|c|}{ pH 7.5} & \multicolumn{3}{|c|}{ pH 6.5} & \multicolumn{3}{|c|}{ factor 2} & \multicolumn{3}{|c|}{ factor 5} & \multicolumn{3}{|c|}{ factor 2} & \multicolumn{3}{|c|}{ factor 2} & \multicolumn{3}{|c|}{ factor 5} \\
\hline \# samples & & & 15 & & & 10 & & & 19 & & & 12 & & & 4 & & & 6 & & & 5 & \\
\hline $\mathrm{pH}$ & & 1.2 & \pm & 0.1 & 1.3 & \pm & 0.1 & 1.1 & \pm & 0.1 & 0.7 & \pm & 0.1 & 0.9 & \pm & 0.1 & 0.9 & \pm & 0.1 & 0.7 & \pm & 0.1 \\
\hline electrical conductivity ${ }^{b}$ & {$\left[\mathrm{mS} \mathrm{cm}^{-1}\right]$} & 44.0 & \pm & 3.9 & 43.4 & \pm & 7.2 & 59.6 & \pm & 17.6 & 174.0 & \pm & 8.0 & 107.0 & \pm & 3.0 & 80.0 & \pm & 15.0 & 111.0 & \pm & 10.0 \\
\hline suspended COD & [mg COD L-1] & 142 & \pm & 7 & 132 & \pm & 15 & & & & & & & & & & & & & & & \\
\hline total nitrogen & [mg N L-1] & 1590 & \pm & 77 & 1530 & \pm & 151 & & & & & & & & & & & & & & & \\
\hline total ammonia nitrogen & {$\left[\mathrm{mg} \mathrm{N} \mathrm{L}^{-1}\right]$} & 0 & \pm & 0 & 1 & \pm & 1 & 0 & \pm & 0 & 0 & \pm & 0 & 0 & \pm & 0 & 2 & \pm & 4 & 0 & \pm & 0 \\
\hline nitrite & {$\left[\mathrm{mg} \mathrm{N} \mathrm{L}^{-1}\right]$} & 0 & \pm & 0 & 0 & \pm & 0 & 0 & \pm & 1 & 0 & \pm & 1 & 0 & \pm & 0 & 0 & \pm & 0 & 0 & \pm & 0 \\
\hline nitrate & [mg N L-1] & 1575 & \pm & 154 & 1443 & \pm & 139 & 2083 & \pm & 320 & 4561 & \pm & 167 & 2621 & \pm & 83 & 2377 & \pm & 105 & 3579 & \pm & 136 \\
\hline phosphate & {$\left[\mathrm{mg} \mathrm{L}^{-1}\right]$} & $287^{a}$ & \pm & 47 & $262^{a}$ & \pm & 60 & 39 & \pm & 67 & 2 & \pm & 7 & 0 & \pm & 0 & 3 & \pm & 7 & 0 & \pm & 0 \\
\hline sulfate & {$\left[\mathrm{mg} \mathrm{L}^{-1}\right]$} & 175 & \pm & 18 & 163 & \pm & 18 & 295 & \pm & 166 & 348 & \pm & 162 & 223 & \pm & 29 & 85 & \pm & 13 & 259 & \pm & 29 \\
\hline chloride & {$\left[\mathrm{mg} \mathrm{L}^{-1}\right]$} & 661 & \pm & 53 & 621 & \pm & 58 & 861 & \pm & 163 & 1909 & \pm & 186 & 1141 & \pm & 68 & 868 & \pm & 53 & 1334 & \pm & 53 \\
\hline sodium & {$\left[\mathrm{mg} \mathrm{L}^{-1}\right]$} & 612 & \pm & 31 & 576 & \pm & 71 & 1130 & \pm & 435 & 241 & \pm & 138 & 323 & \pm & 202 & 863 & \pm & 22 & 1201 & \pm & 62 \\
\hline potassium & {$\left[\mathrm{mg} \mathrm{L}^{-1}\right]$} & 547 & \pm & 7 & 555 & \pm & 73 & 20 & \pm & 27 & 23 & \pm & 31 & 5 & \pm & 1 & 802 & \pm & 18 & 1340 & \pm & 150 \\
\hline
\end{tabular}

${ }^{a}$ High phosphate concentration in the middle compartment effluent is caused by diffusion of phosphate from the anolyte $\left(\mathrm{KH}_{2} \mathrm{PO}_{4}\right)$ through the $\mathrm{CEM}$

b The high electrical conductivity is caused by the very high specific conductivity of protons 
Table S4. Composition of the anodic compartment effluent of the full nitrification reactor with electrochemical hydroxide addition.

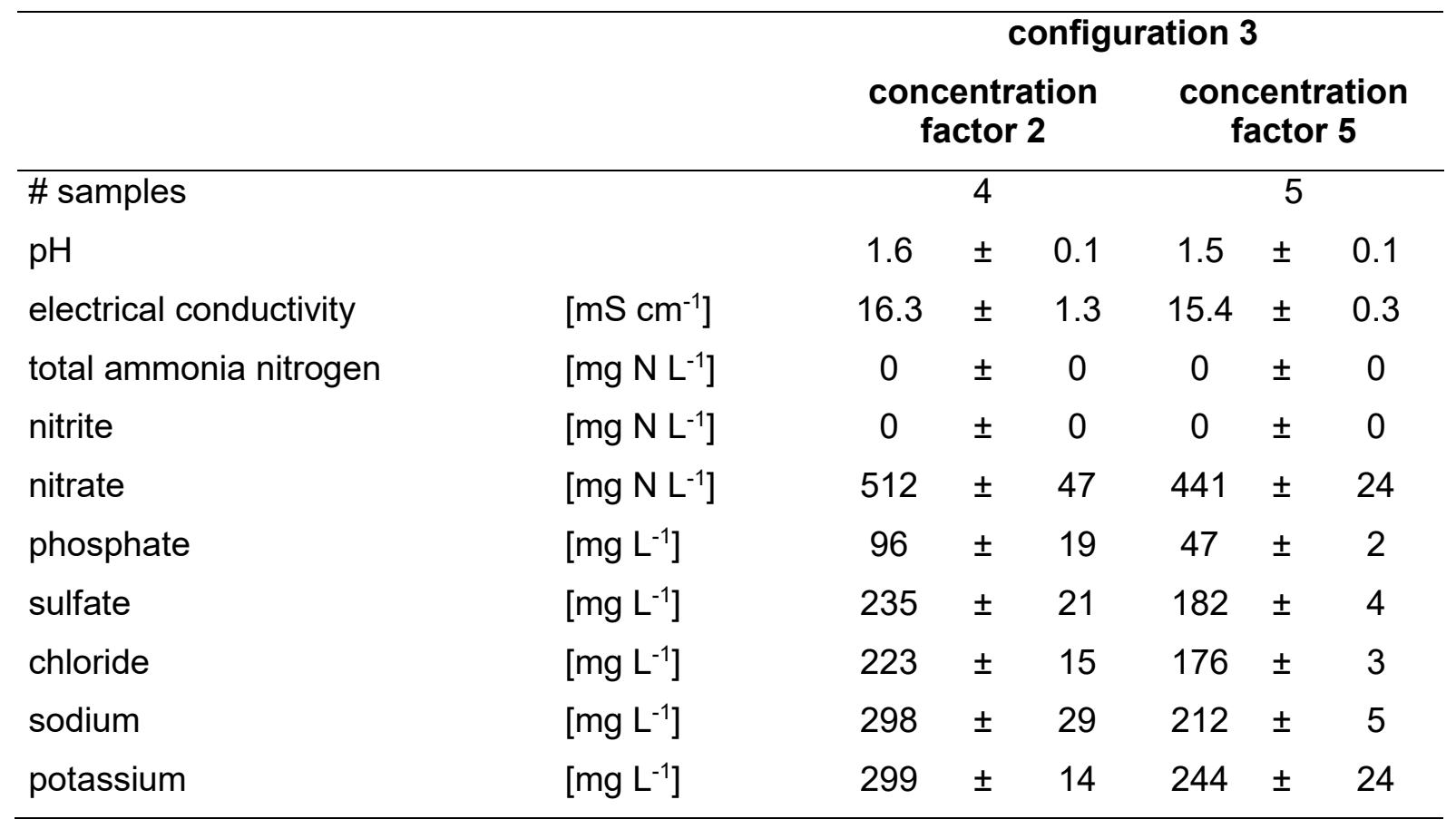



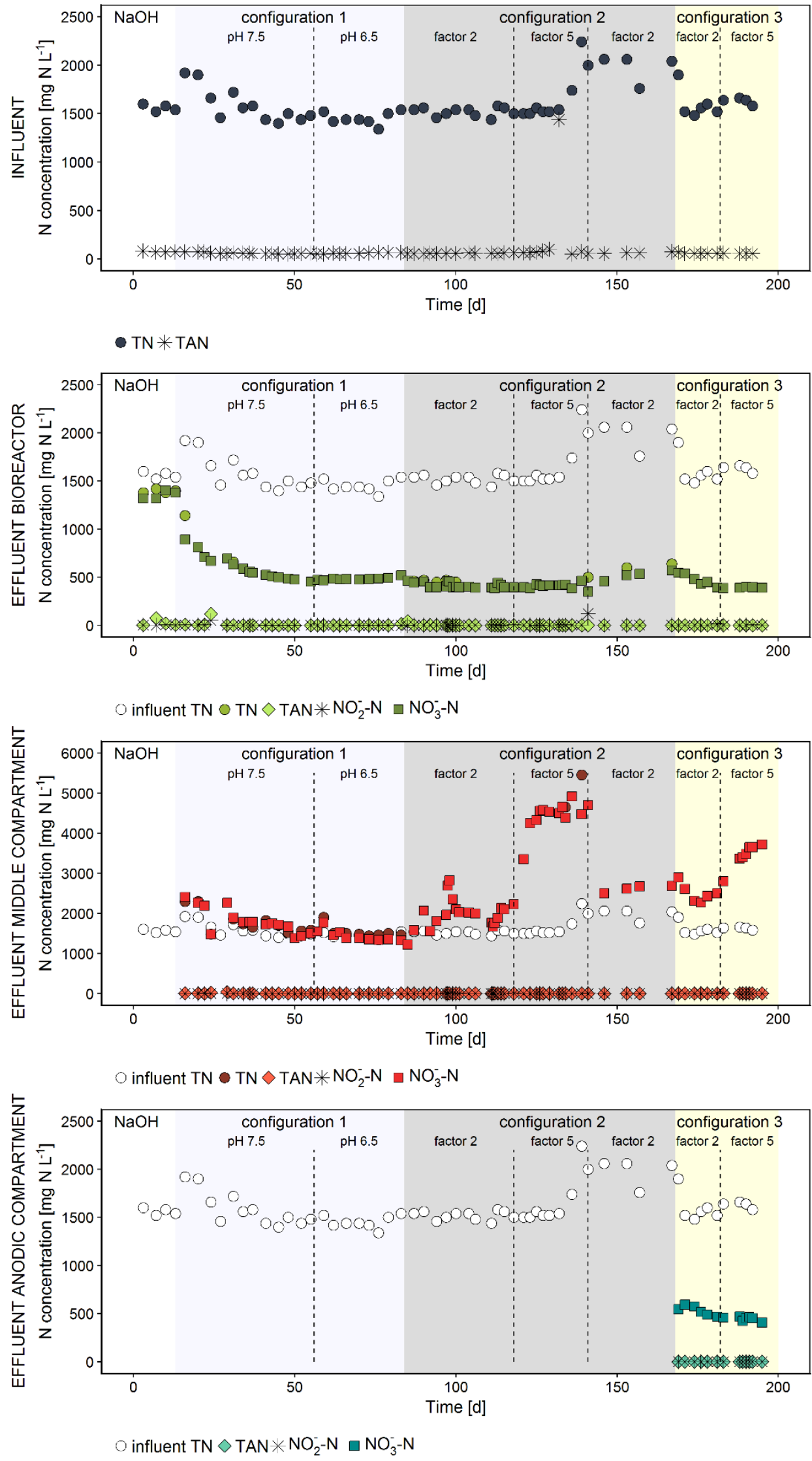

Figure S5. Nitrogen species in the influent and effluent of the bioreactor, middle compartment and anodic compartment. 

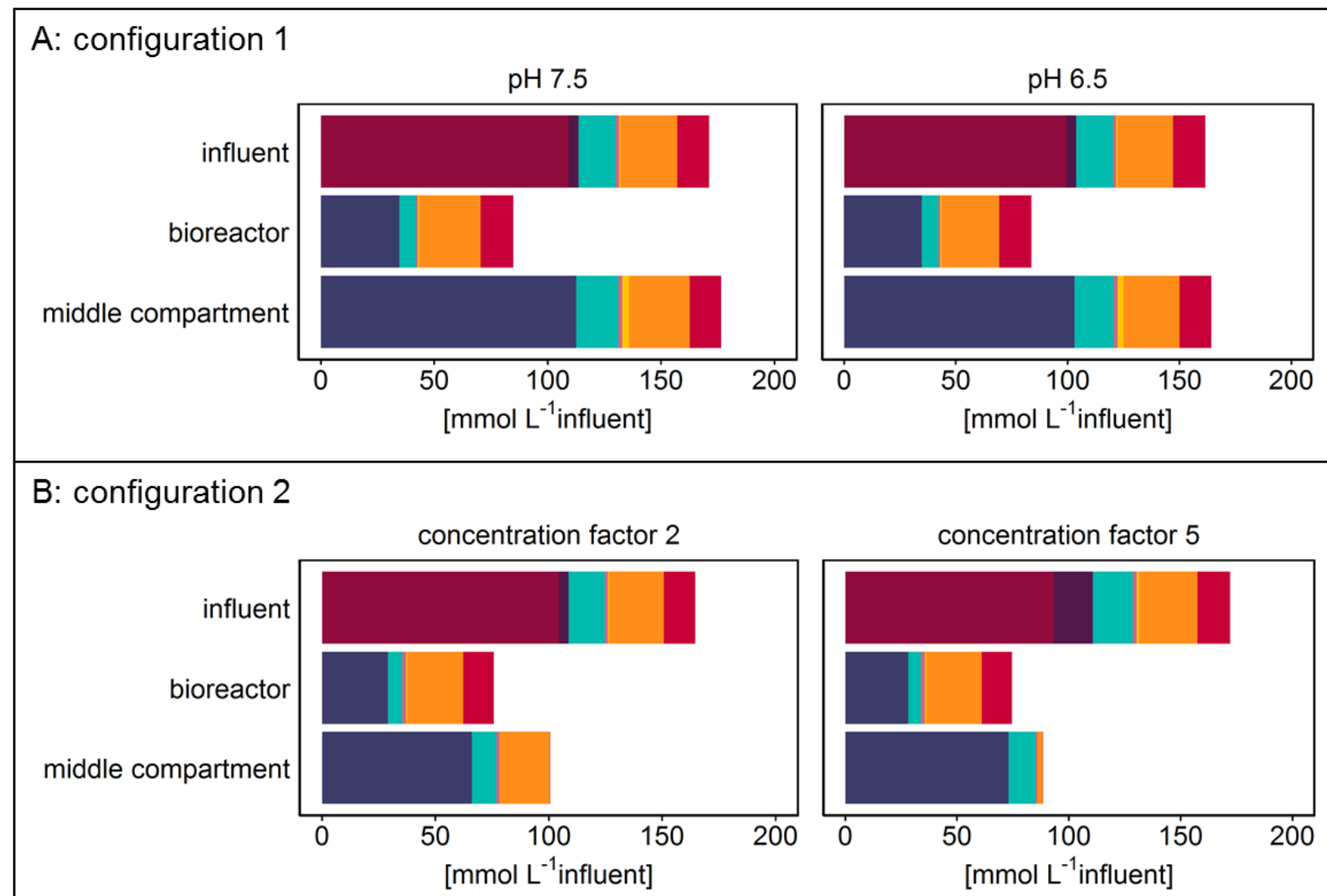

C: configuration 3
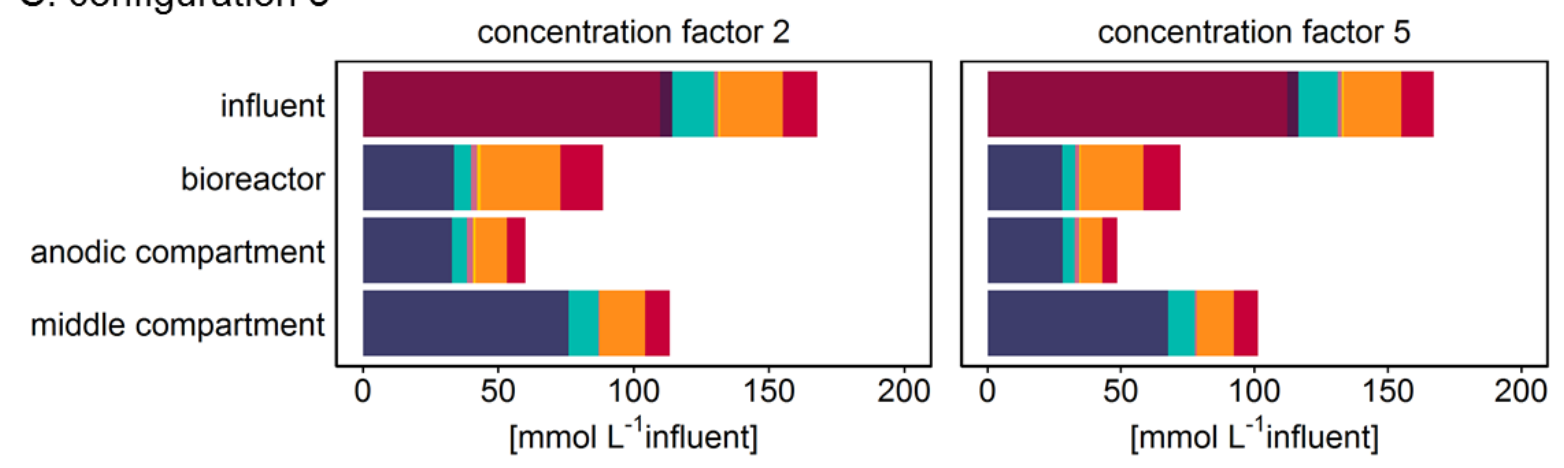

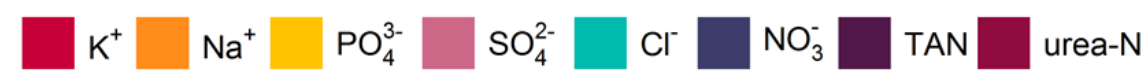

Figure S6. Mass balance: composition of the influent, bioreactor liquid, middle compartment and anodic compartment in configuration 1-3 scaled by the influent volume (i.e., the concentration [mmol $\left.\mathrm{L}^{-1}\right]$ multiplied by the flow rate $\left[\mathrm{L} \mathrm{d}^{-1}\right]$ divided by the influent flow rate [ $\mathrm{L}$ influent $\left.\left.d^{-1}\right]\right)$. 
B2. Electrochemical hydroxide production and energy consumption

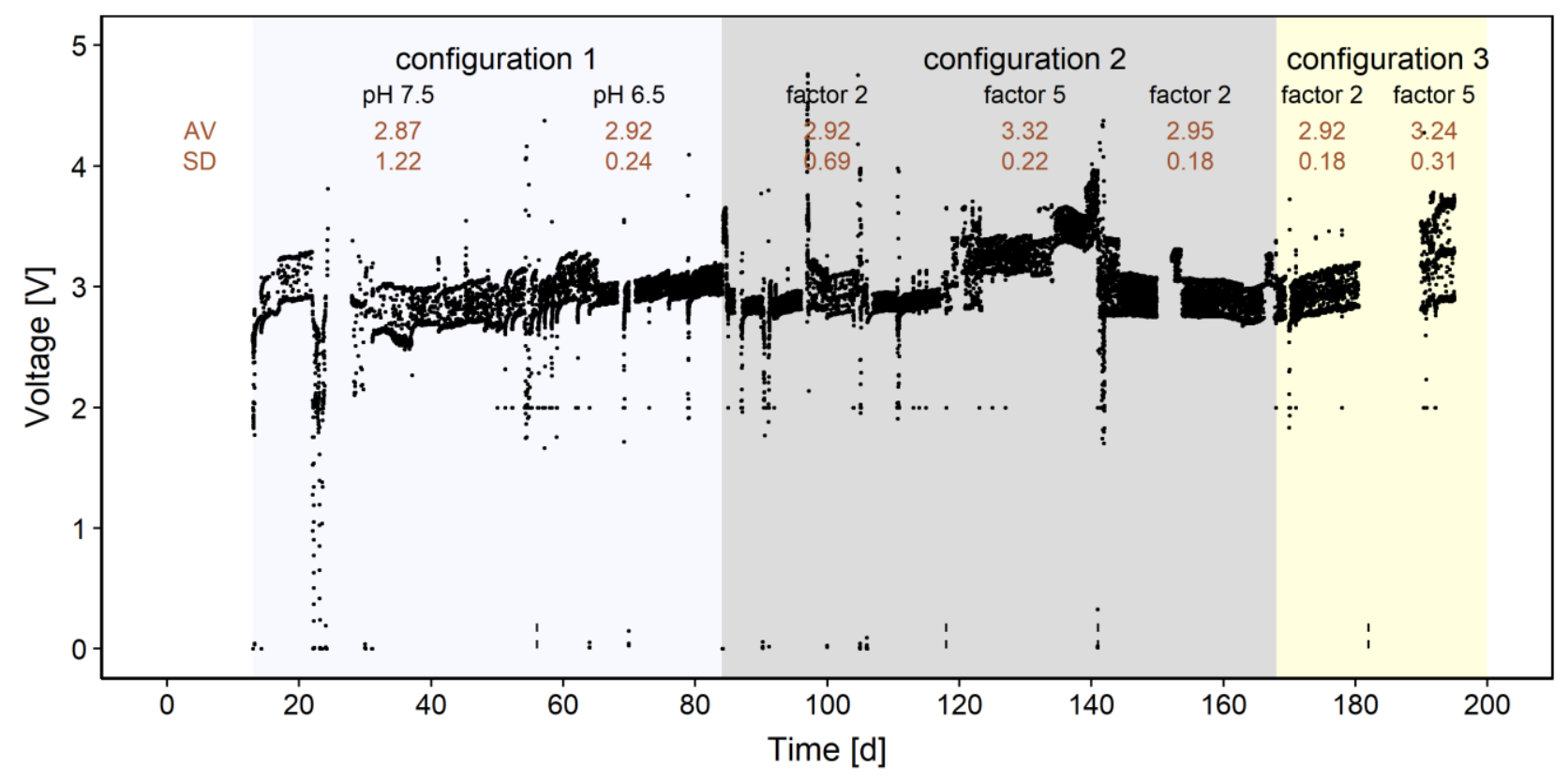

Figure S7. Voltage applied by the electrochemical cell. Averages (AV) and standard deviations (SD) for each operational phase are displayed. 
Table S5. Electrode energy consumption.

\begin{tabular}{|c|c|c|c|c|c|c|c|}
\hline & & \multicolumn{2}{|c|}{ Configuration 1} & \multicolumn{2}{|c|}{ Configuration 2} & \multicolumn{2}{|c|}{ Configuration 3} \\
\hline & & pH 7.5 & pH 6.5 & $\begin{array}{c}\text { concentration } \\
\text { factor } 2\end{array}$ & $\begin{array}{c}\text { concentration } \\
\text { factor } 5\end{array}$ & $\begin{array}{c}\text { concentration } \\
\text { factor } 2\end{array}$ & $\begin{array}{c}\text { concentration } \\
\text { factor } 5\end{array}$ \\
\hline Average current & {$[\mathrm{A}]$} & 0.055 & 0.056 & 0.062 & 0.139 & 0.071 & 0.100 \\
\hline Average voltage & [V] & 2.87 & 2.92 & 2.92 & 3.32 & 2.92 & 3.24 \\
\hline \multirow[t]{2}{*}{ Influent flow rate } & {$\left[\mathrm{L}\right.$ influent $\left.\mathrm{d}^{-1}\right]$} & 0.49 & 0.49 & 0.50 & 0.53 & 0.45 & 0.47 \\
\hline & {$\left[L\right.$ urine $\left.d^{-1}\right]$} & 0.16 & 0.16 & 0.17 & 0.18 & 0.15 & 0.16 \\
\hline Electrode & {$\left[\mathrm{kWh} \mathrm{m}^{-3}\right]$} & 7.8 & 8.0 & 8.7 & 20.9 & 11.1 & 16.5 \\
\hline energy & {$\left[\mathrm{kWh}_{\mathrm{el}} \mathrm{m}^{-3}\right.$ urine] } & 23.5 & 23.9 & 26.1 & 62.6 & 33.4 & 49.4 \\
\hline \multirow[t]{2}{*}{ consumption ${ }^{a}$} & $\begin{array}{l}\text { [kWh }_{\text {prim }} \\
\mathrm{m}^{-3} \text { urine] }^{\mathrm{b}}\end{array}$ & 75.7 & 76.9 & 84.1 & 201.9 & 107.7 & 159.3 \\
\hline & $\begin{array}{l}{\left[\mathrm{kWh}_{\text {el }} \mathrm{kg} \mathrm{NO}_{3}^{-}-\mathrm{N}\right.} \\
\text { recovered] }\end{array}$ & 4.3 & 5.5 & 9.4 & 20.5 & 10.5 & 17.4 \\
\hline
\end{tabular}

${ }^{\mathrm{b}}$ using a conversion factor of $0.31 \mathrm{Wh} / \mathrm{Wh}$ prim for electricity production from Udert and Wachter $(2012)^{3}$ 
Table S6. Estimated hydroxide demand for full nitrification compared to the total hydroxide addition. The hydroxide demand for full nitrification was estimated based on the average total nitrogen (TN) concentration in the influent, assuming that $1 \mathrm{~mol} \mathrm{OH}^{-} \mathrm{mol}^{-1} \mathrm{~N}$ is required to obtain full nitrification. The hydroxide addition in the pre-treatment and hydroxide addition by the electrochemical cell in the recirculation loop of the bioreactor are estimated based on the current and influent flow (Equation 1).

\begin{tabular}{|c|c|c|c|c|c|c|c|}
\hline & & \multicolumn{2}{|c|}{ Configuration 1} & \multicolumn{2}{|c|}{ Configuration 2} & \multicolumn{2}{|c|}{ Configuration 3} \\
\hline & & pH 7.5 & $\mathrm{pH} 6.5$ & $\begin{array}{l}\text { concentration } \\
\text { factor } 2\end{array}$ & $\begin{array}{l}\text { concentration } \\
\text { factor } 5\end{array}$ & $\begin{array}{l}\text { concentration } \\
\text { factor } 2\end{array}$ & $\begin{array}{l}\text { concentration } \\
\text { factor } 5\end{array}$ \\
\hline $\begin{array}{l}\text { Average influent TN } \\
\text { concentration }\end{array}$ & {$\left[\mathrm{mg} \mathrm{N} \mathrm{L}^{-1}\right]$} & 1588 & 1453 & 1520 & 1548 & 1597 & 1630 \\
\hline $\mathrm{OH}^{-}$demand for full nitrification & {$\left[\mathrm{mmol} \mathrm{OH} \mathrm{L}^{-1}\right]$} & 113 & 104 & 109 & 111 & 114 & 116 \\
\hline $\mathrm{OH}^{-}$addition in pre-treatment & {$\left[\mathrm{mmol} \mathrm{OH} \mathrm{L}^{-1}\right]$} & 29 & 29 & 29 & 29 & 29 & 29 \\
\hline $\mathrm{OH}^{-}$addition in bioreactor & {$\left[\mathrm{mmol} \mathrm{OH} \mathrm{L}^{-1}\right]$} & 101 & 101 & 111 & 234 & 142 & 190 \\
\hline Total $\mathrm{OH}^{-}$addition & {$\left[\mathrm{mmol} \mathrm{OH} \mathrm{LL}^{-1}\right]$} & 130 & 130 & 140 & 263 & 161 & 219 \\
\hline
\end{tabular}

$O H^{-}$addition $\left[\mathrm{mol} \mathrm{OH} L^{-1}\right]=\frac{I[A] *(24 * 60 * 60)\left[\frac{S}{d}\right]}{96485.3329\left[\frac{C}{\text { mol e }^{-}}\right] * 1 \frac{\mathrm{mol} \mathrm{e}^{-}}{\text {mol OH }^{-}} * Q_{\text {in bioreactor }}\left[\frac{L}{d}\right]}$

(Equation 1) 

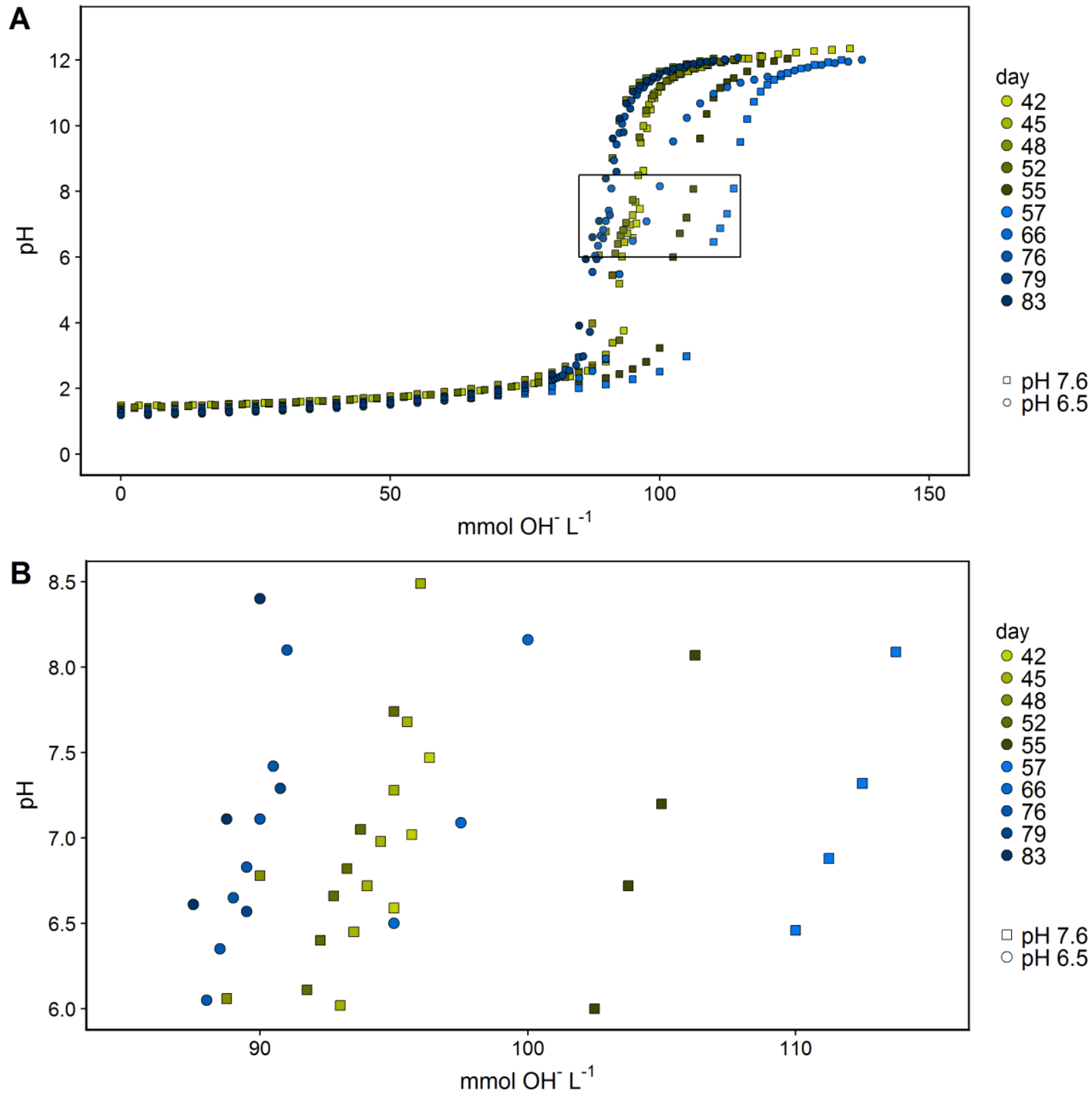

Figure S8. Titration curves of the effluent of the middle compartment in configuration 1. About $90-115 \mathrm{mmol} \mathrm{OH}^{-} \mathrm{L}^{-1}$ was required to increase the $\mathrm{pH}$ to 6.5-7.5. 


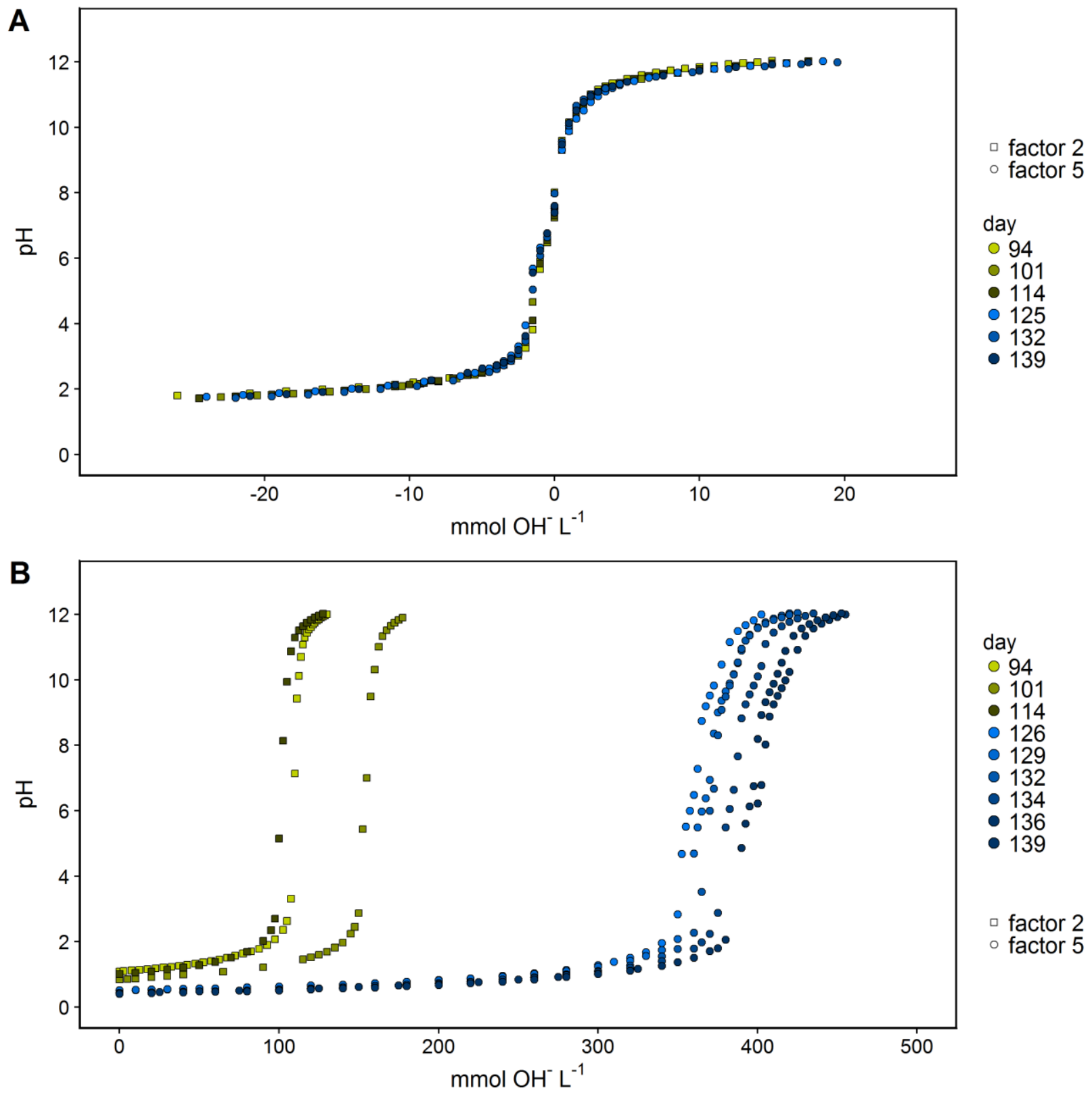

Figure S9. Titration curves of the effluent of the bioreactor (A) and middle compartment (B) in configuration 2. 


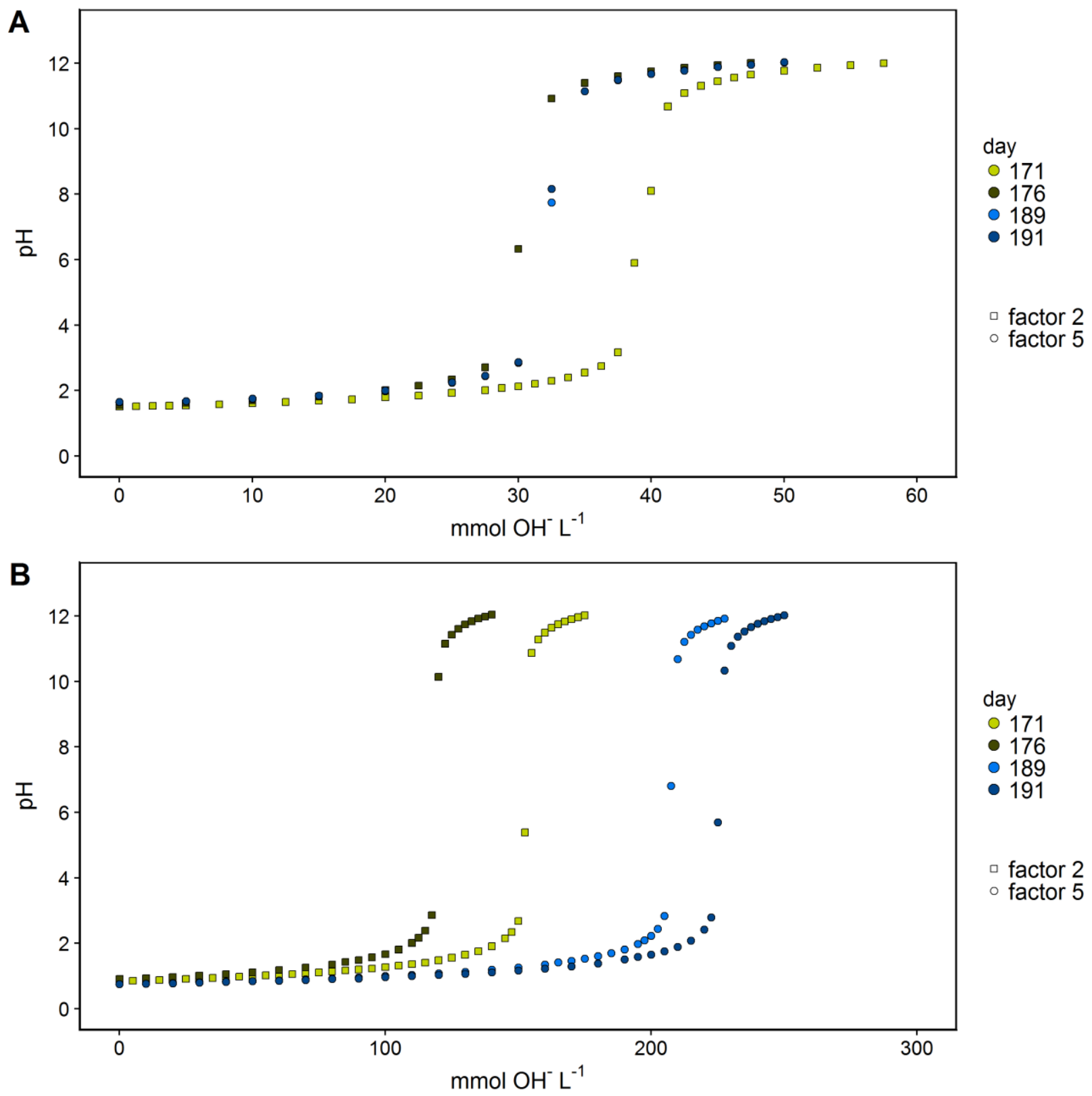

Figure S10. Titration curves of the effluent of the anodic compartment (A) and middle compartment $(B)$ in configuration 3. 


\section{B3. Electromigration}

\section{$\underline{\text { Calculations }}$}

Based on the electric charge that was applied by the electrochemical cell, the amount of electrons that went from the anode to the cathode in one HRT (in the bioreactor) was determined as follows:

$$
\left[\text { mmol } e^{-} \text {per HRT }\right]=\frac{H R T[d] * \text { current }[A] *(24 * 60 * 60)\left[\frac{s}{d}\right]}{96485.3 \frac{C}{m o l} e^{-}} * 10^{3}
$$

An equal amount of charge should migrate between the compartments to restore the charge balance. For the AEM, the relative contributions of nitrate, chloride, sulfate and phosphate to the total migration were calculated as follows:

relative contribution $[\%]$

$$
=\frac{\left(Q_{\text {influent }}^{-}\left[\frac{\mathrm{mmol}}{L}\right]-Q_{\text {bioreactor }}^{-}\left[\frac{\mathrm{mmol}}{L}\right]\right) * V_{M B B R}[L] * \text { valence of ion }}{\text { amount of electrons }\left[\mathrm{mmol}^{-}\right]} * 100
$$

with

- $Q_{\text {influent }}^{-}\left[\frac{\mathrm{mmol}}{\mathrm{L}}\right]=$ concentration of anion in influent (for nitrate, the total nitrogen concentration in the influent was used)

- $Q_{\text {bioreactor }}^{-}\left[\frac{\mathrm{mmol}}{\mathrm{L}}\right]=$ concentration of anion in bioreactor

- $\quad V_{M B B R}[L]=$ volume of the MBBR (+ cathodic compartment)

- valence of ion $=-1$ for chloride and nitrate, -2 for sulfate and phosphate $\left(\mathrm{HPO}_{4}{ }^{2-}\right.$ is the dominating speciation at $\mathrm{pH} 7$ )

- amount of electrons $\left[\mathrm{mmol}^{-}\right]=$amount of electrons that were transferred from anode to cathode in one HRT

For the CEM in configuration 3, the relative contributions of sodium, potassium and protons to the total migration were calculated as follows:

relative contribution [\%]

$=\frac{\left(Q_{\text {bioreacor }}^{+}\left[\frac{\mathrm{mmol}}{L}\right]-Q_{\text {effluent anodic compartment }}^{+}\left[\frac{\mathrm{mmol}}{\mathrm{L}}\right]\right) * V_{M B B R}[L] * \text { valence of ion }}{\text { amount of electrons }\left[\mathrm{mmol} e^{-}\right]} * 100$ 
with

- $Q_{\text {bioreactor }}^{+}\left[\frac{\mathrm{mmol}}{\mathrm{L}}\right]=$ concentration of cation in the bioreactor

- Na effluent anodic compartment $\left[\frac{\mathrm{mmol}}{\mathrm{L}}\right]=$ concentration of cation in the effluent of the anodic compartment

- $\quad V_{M B B R}[L]=$ volume of the bioreactor

- valence of ion $=+1$

- amount of electrons $\left[\mathrm{mmol} \mathrm{e}^{-}\right]=$amount of electrons that were transferred from anode to cathode in one HRT

Table S7. Contribution of nitrate, chloride, phosphate and sulfate to the total electromigration through the AEM. Q- includes hydroxide ions, carbonate ions, and protons (diffusing through the AEM).

\begin{tabular}{llllll}
\hline & $\mathbf{N O}_{3}{ }^{-}$ & $\mathbf{C l}^{-}$ & $\mathbf{S O}{ }^{2-}$ & $\mathbf{H P O}_{4}{ }^{2-}$ & $\mathbf{Q}^{-}$ \\
\hline $\begin{array}{l}\text { Configuration 1 } \\
\mathrm{pH} \mathrm{7.5}\end{array}$ & 77.8 & 8.8 & 1.4 & 0.1 & 11.9 \\
$\mathrm{pH} \mathrm{6.5}$ & 68.3 & 9.0 & 1.0 & 0 & 22.1 \\
\hline $\begin{array}{l}\text { Configuration 2 } \\
\text { Factor 2 }\end{array}$ & 71.0 & 8.6 & 0 & 0 & 20.8 \\
$\quad$ Factor 5 & 34.7 & 5.2 & 0 & 0.1 & 60.2 \\
\hline Configuration 3 & & & & & \\
Factor 2 & 55.9 & 6.4 & 0 & 0 & 37.8 \\
Factor 5 & 46.6 & 5.3 & 0 & 0 & 48.1 \\
\hline
\end{tabular}

Table S8. Contribution of sodium, potassium and protons to the total electromigration through the CEM.

\begin{tabular}{llll}
\hline & $\mathbf{N a}^{+}$ & $\mathbf{K}^{+}$ & $\mathbf{H}^{+}\left(\mathbf{1 0 0}-\mathbf{N a}^{+}-\mathbf{K}^{+}\right)$ \\
\hline Configuration 3 & & & \\
Factor 2 & 11.5 & 5.6 & 82.9 \\
Factor 5 & 7.5 & 4.1 & 88.4 \\
\hline
\end{tabular}




\section{Partial nitrification (PN) without pH control}

\section{C1. Materials and methods}

\section{C1.1. Experimental setup}

The partial nitrification reactor without $\mathrm{pH}$ control consisted of the same basic MBBR design as the MBBR used for electrochemical pH control (without electrochemical cell).

\section{C1.2. Operation of the partial nitrification (PN) reactor without $\mathrm{pH}$ control}

After a start-up of 70 days, the target loading rate was reached (corresponds to 'day 1') and the MBBR was operated for 52 days on electrochemically alkalinized urine (at a $\mathrm{pH}$ of $11.9 \pm 0.2$, containing $\sim 29 \mathrm{mmol} \mathrm{OH}^{-} \mathrm{L}^{-1}$ ) (PN-I) (Table S9). In order to investigate if the $\mathrm{NO}_{3}{ }^{-} \mathrm{N} / \mathrm{TAN}$ ratio in the effluent could be increased by feeding more alkaline influent, the MBBR was fed with $\mathrm{NaOH}$ alkalinized urine containing $66 \mathrm{mmol} \mathrm{NaOH} \mathrm{L}^{-1}$ between day 73 and 126 (PN-III). Prior to PN-III, the bioreactor was conditioned with $\mathrm{NaOH}$-alkalinized influent $\left(22 \mathrm{mmol} \mathrm{NaOH} \mathrm{L}^{-1}\right.$ to obtain the same influent $\mathrm{pH}$ of $11.8 \pm 0.3$ as in $\mathrm{PN}-\mathrm{I})$ between day 52 and $73(\mathrm{PN}-\mathrm{II})$. 
Table S9. Overview of the different operational phases of the partial nitrification reactor without pH control. Average influent and effluent compositions are reported in Section C2. HRT: hydraulic residence time.

\begin{tabular}{|c|c|c|c|c|}
\hline & \multirow[t]{2}{*}{ PN-I } & \multirow[t]{2}{*}{ PN-II } & \multicolumn{2}{|c|}{ PN-III } \\
\hline & & & PN-IIla & PN-IIIb \\
\hline Influent alkalinization method & $\begin{array}{c}\text { electrochemical } \\
\mathrm{OH}^{-} \text {addition }\end{array}$ & $\mathrm{NaOH}$ addition & $\mathrm{NaOH}$ addition & $\mathrm{NaOH}$ addition \\
\hline Hydroxide dosage & $\sim 29 \mathrm{mmol} \mathrm{OH}^{-} \mathrm{L}^{-1}$ & $22 \mathrm{mmol} \mathrm{OH} \mathrm{L}^{-1}$ & $\begin{array}{l}66 \mathrm{mmol} \mathrm{OH}^{-} \mathrm{L}^{-1} \\
\text { (batch } 1+2)\end{array}$ & $\begin{array}{l}66 \mathrm{mmol} \mathrm{OH}^{-} \mathrm{L}^{-1} \\
\text { (batch 3) }^{a}\end{array}$ \\
\hline Day & $1-52$ & $52-73$ & $73-115$ & $115-126$ \\
\hline HRT & $7.0 \pm 0.3$ & $7.0 \pm 0.1$ & $7.0 \pm 0.2$ & $6.9 \pm 0.3$ \\
\hline [number of HRT] & 6.4 & 3.1 & 6.1 & 1.6 \\
\hline Influent flow rate $Q_{\text {in }} \quad\left[\mathrm{L} \mathrm{d}^{-1}\right]$ & $460 \pm 17$ & $458 \pm 4$ & $457 \pm 15$ & $479 \pm 8$ \\
\hline$\left[\mathrm{mg} \mathrm{N} \mathrm{d}^{-1}\right]$ & $807 \pm 59$ & $884 \pm 54$ & $790 \pm 48$ & $331 \pm 43$ \\
\hline $\mathrm{N}$ loading rate ${ }^{\mathrm{b}}$ & $251 \pm 18$ & $274 \pm 17$ & $245 \pm 15$ & $103 \pm 13$ \\
\hline COD load $\quad\left[\mathrm{mg} \mathrm{COD} \mathrm{d}^{-1}\right]$ & $677 \pm 29$ & $1057 \pm 28$ & $912 \pm 71$ & $426 \pm 7$ \\
\hline COD loading rate $^{\mathrm{b}} \quad\left[\mathrm{mg} \mathrm{COD} \mathrm{L}^{-1} \mathrm{~d}^{-1}\right]$ & $210 \pm 9$ & $328 \pm 9$ & $283 \pm 22$ & $132 \pm 2$ \\
\hline
\end{tabular}

a Batch 3 is represented separately since this batch was less concentrated which resulted in a substantially lower N and COD load

${ }^{\mathrm{b}}$ Reactor volume $=3.2 \mathrm{~L}$ 


\section{C2. Influent and effluent composition}

Table S10. Influent composition of the partial nitrification reactor without pH control.

\begin{tabular}{|c|c|c|c|c|c|c|c|c|c|c|c|c|c|}
\hline & & \multirow{2}{*}{\multicolumn{3}{|c|}{ PN-I }} & \multirow{2}{*}{\multicolumn{3}{|c|}{ PN-II }} & \multicolumn{6}{|c|}{ PN-III } \\
\hline & & & & & & & & \multicolumn{3}{|c|}{ PN-IIla } & \multicolumn{3}{|c|}{ PN-IIIb } \\
\hline $\begin{array}{l}\text { influent alkalinisation } \\
\text { method }\end{array}$ & & \multicolumn{3}{|c|}{$\begin{array}{l}\text { electrochemical } \mathrm{OH}- \\
\text { addition }\end{array}$} & \multicolumn{3}{|c|}{$\mathrm{NaOH}$ addition } & \multicolumn{3}{|c|}{$\mathrm{NaOH}$ addition } & \multicolumn{3}{|c|}{$\mathrm{NaOH}$ addition } \\
\hline hydroxide dosage & & \multicolumn{3}{|c|}{$\sim 29 \mathrm{mmol} \mathrm{OH} \mathrm{OH}^{-1}$} & \multicolumn{3}{|c|}{$22 \mathrm{mmol} \mathrm{OH}^{-} \mathrm{L}^{-1}$} & \multicolumn{3}{|c|}{$\begin{array}{l}66 \mathrm{mmol} \mathrm{OH}^{-} \mathrm{L}^{-1} \\
\text { (batch } 1+2)\end{array}$} & \multicolumn{3}{|c|}{$\begin{array}{c}66 \mathrm{mmol} \mathrm{OH}^{-} \mathrm{L}^{-1} \\
\text { (batch 3) }^{\mathrm{a}}\end{array}$} \\
\hline number of samples & & \multicolumn{3}{|c|}{18} & \multicolumn{3}{|c|}{8} & \multicolumn{3}{|c|}{15} & \multicolumn{3}{|c|}{5} \\
\hline $\mathrm{pH}$ & & 11.9 & \pm & 0.2 & 11.8 & \pm & 0.3 & 12.8 & \pm & 0.2 & 12.6 & \pm & 0.1 \\
\hline electrical conductivity & {$\left[\mathrm{mS} \mathrm{cm}^{-1}\right]$} & 3.9 & \pm & 0.4 & $7.0^{b}$ & \pm & 1.1 & $15.2^{b}$ & \pm & 0.8 & $16.1^{b}$ & \pm & 0.1 \\
\hline suspended COD & [mg COD L-1] & 1468 & \pm & 43 & 2151 & \pm & 389 & 1975 & \pm & 184 & 882 & \pm & 20 \\
\hline total nitrogen & [mg N L-1] & 1710 & \pm & 150 & 1863 & \pm & 217 & 1706 & \pm & 126 & 668 & \pm & 90 \\
\hline total ammonia nitrogen & [mg N L-1] & 72 & \pm & 8 & 69 & \pm & 7 & 66 & \pm & 5 & 35 & \pm & 1 \\
\hline nitrite & [mg N L-1] & 1 & \pm & 1 & 0 & \pm & 0 & 1 & \pm & 0 & 1 & \pm & 0 \\
\hline nitrate & [mg N L-1] & 3 & \pm & 1 & 6 & \pm & 1 & 7 & \pm & 2 & 8 & \pm & 3 \\
\hline phosphate & {$\left[\mathrm{mg} \mathrm{L}^{-1}\right]$} & $76^{c}$ & \pm & 31 & 137 & \pm & 44 & 188 & \pm & 31 & 61 & \pm & 23 \\
\hline sulfate & {$\left[\mathrm{mg} \mathrm{L}^{-1}\right]$} & $127^{c}$ & \pm & 8 & 255 & \pm & 58 & 274 & \pm & 25 & 163 & \pm & 14 \\
\hline chloride & {$\left[\mathrm{mg} \mathrm{L}^{-1}\right]$} & $510^{c}$ & \pm & 59 & 1157 & \pm & 264 & 1125 & \pm & 152 & 525 & \pm & 47 \\
\hline sodium & {$\left[\mathrm{mg} \mathrm{L}^{-1}\right]$} & 588 & \pm & 42 & $1125^{b}$ & \pm & 233 & $1855^{b}$ & \pm & 131 & $1793^{b}$ & \pm & 25 \\
\hline potassium & {$\left[\mathrm{mg} \mathrm{L}^{-1}\right]$} & 553 & \pm & 18 & 662 & \pm & 53 & 665 & \pm & 100 & 306 & \pm & 54 \\
\hline
\end{tabular}

a Batch 3 is represented separately since this batch was less concentrated resulting is a substantially lower N and COD loading

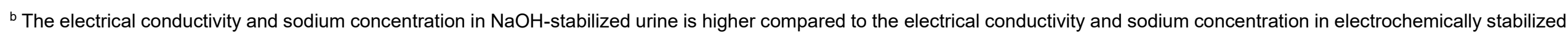
urine because of the $\mathrm{NaOH}$ addition

${ }^{\mathrm{c}} \mathrm{A}$ part of the phosphate, sulfate and chloride in urine was removed by migration in the electrochemical pre-treatment 


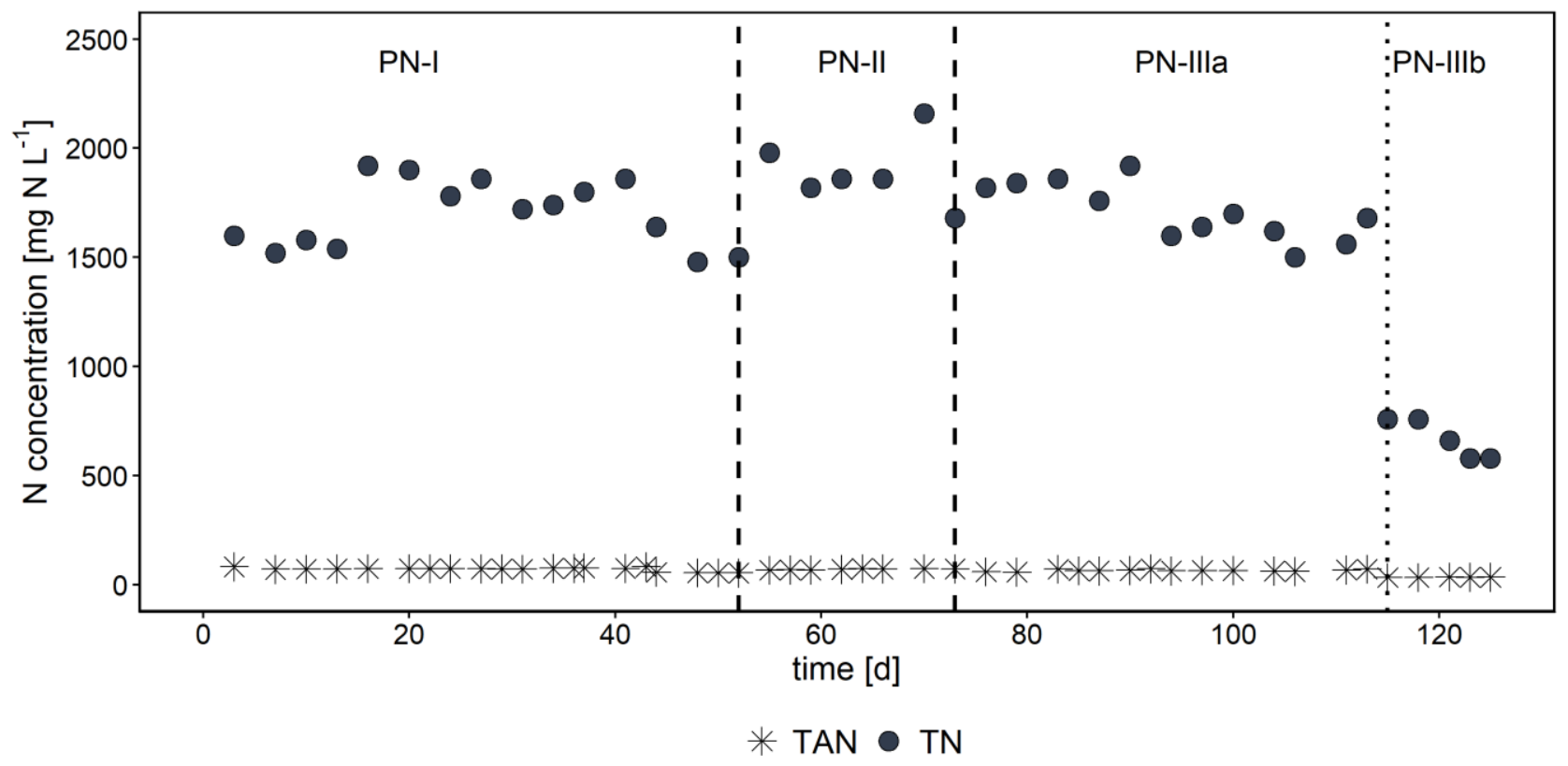

Figure S11. Total nitrogen (TN) and total ammonia nitrogen (TAN) concentration in the influent of the partial nitrification reactor without $\mathrm{pH}$ control. The influent used in PN-I was stabilized with an electrochemical cell, whereas $\mathrm{NaOH}$ was used to stabilize the influent in phase PN-II to PNIII. 
Table S11. Effluent composition of the partial nitrification reactor without $\mathrm{pH}$ control.

\begin{tabular}{|c|c|c|c|c|c|c|c|c|c|c|c|c|c|}
\hline & & \multirow{2}{*}{\multicolumn{3}{|c|}{ PN-I }} & \multirow{2}{*}{\multicolumn{3}{|c|}{ PN-II }} & \multicolumn{6}{|c|}{ PN-III } \\
\hline & & & & & & & & \multicolumn{3}{|c|}{ PN-IIla } & \multicolumn{3}{|c|}{ PN-IIIb } \\
\hline $\begin{array}{l}\text { Influent alkalinisation } \\
\text { method }\end{array}$ & & \multicolumn{3}{|c|}{$\begin{array}{l}\text { electrochemical } \mathrm{OH}- \\
\text { addition }\end{array}$} & \multicolumn{3}{|c|}{$\mathrm{NaOH}$ addition } & \multicolumn{3}{|c|}{$\mathrm{NaOH}$ addition } & \multicolumn{3}{|c|}{$\mathrm{NaOH}$ addition } \\
\hline Hydroxide dosage & & \multicolumn{3}{|c|}{$\sim 29 \mathrm{mmol} \mathrm{OH} \mathrm{L}^{-1}$} & \multicolumn{3}{|c|}{$22 \mathrm{mmol} \mathrm{OH}^{-} \mathrm{L}^{-1}$} & \multicolumn{3}{|c|}{$\begin{array}{l}66 \mathrm{mmol} \mathrm{OH}^{-} \mathrm{L}^{-1} \\
\quad(\text { batch } 1+2)\end{array}$} & \multicolumn{3}{|c|}{$\begin{array}{l}66 \mathrm{mmol} \mathrm{OH}^{-} \mathrm{L}^{-1} \\
{\text { (batch } 3)^{\mathrm{a}}}^{\text {a }}\end{array}$} \\
\hline \# samples & & \multicolumn{3}{|c|}{18} & \multicolumn{3}{|c|}{8} & \multicolumn{3}{|c|}{15} & \multicolumn{3}{|c|}{5} \\
\hline electrical conductivity & {$\left[\mathrm{mS} \mathrm{cm}^{-1}\right]$} & 10.4 & \pm & 1.1 & 13.1 & \pm & 1.1 & 15.1 & \pm & 0.5 & 12.1 & \pm & 1.5 \\
\hline suspended COD & {$\left[\mathrm{mg} \mathrm{COD} \mathrm{L}{ }^{-1}\right]$} & 212 & \pm & 29 & 246 & \pm & 64 & 141 & \pm & 7 & 112 & \pm & 14 \\
\hline total nitrogen & {$\left[\mathrm{mg} \mathrm{N} \mathrm{L}^{-1}\right]$} & 1697 & \pm & 152 & 1790 & \pm & 75 & 1815 & \pm & 69 & 1240 & \pm & 205 \\
\hline total ammonia nitrogen & {$\left[\mathrm{mg} \mathrm{N} \mathrm{L}^{-1}\right]$} & 621 & \pm & 56 & 707 & \pm & 13 & 498 & \pm & 99 & 166 & \pm & 107 \\
\hline nitrite & {$\left[\mathrm{mg} \mathrm{N} \mathrm{L}^{-1}\right]$} & 9 & \pm & 3 & 4 & \pm & 3 & 1 & \pm & 1 & 1 & \pm & 2 \\
\hline chloride & {$\left[\mathrm{mg} \mathrm{L}^{-1}\right]$} & 540 & \pm & 75 & 1007 & \pm & 178 & 1173 & \pm & 71 & 778 & \pm & 122 \\
\hline sodium & {$\left[\mathrm{mg} \mathrm{L}^{-1}\right]$} & 598 & \pm & 50 & 975 & \pm & 158 & 1867 & \pm & 157 & 1946 & \pm & 36 \\
\hline potassium & {$\left[\mathrm{mg} \mathrm{L}^{-1}\right]$} & 542 & \pm & 22 & 636 & \pm & 20 & 643 & \pm & 56 & 480 & \pm & 58 \\
\hline
\end{tabular}

a Batch 3 is represented separately since this batch was less concentrated resulting is a substantially lower $\mathrm{N}$ concentration in the effluent 


\section{C3. Extent of nitrification as a function of the influent alkalinity}

\section{The extent of nitrification ( $\mathrm{NO}_{3}{ }^{-}-\mathrm{N} / \mathrm{TAN}$ ratio in the effluent) increases as a function of the influent alkalinity}

The extent of nitrification on alkalinized urine ( $\mathrm{pH}$ influent $\geq 11.9$ ) was studied in the MBBR without $\mathrm{pH}$ control. In a first phase (PN-I), with an influent $\mathrm{pH}$ of $11.9 \pm 0.2$, about $40 \%$ of the nitrogen in the effluent consisted of TAN, whereas $\sim 60 \%$ was nitrified to nitrate (Figure $\mathrm{S} 12$ ). This $\mathrm{NO}_{3}{ }^{-}-\mathrm{N} / \mathrm{TAN}$ ratio $(60: 40)$ is higher than reported in literature (typically $\sim 50: 500^{4-6}$ ), because of the $\mathrm{OH}^{-}$addition in the electrochemical pre-treatment ( $29 \mathrm{mmol} \mathrm{OH}^{-} \mathrm{L}^{-1}$, assuming a coulombic efficiency of 100\%). Notably, the observed $60 \%$ of nitrification corresponds well with the interpolated value of $62 \%$, calculated by comparing the added $\mathrm{OH}^{-}$equivalents to the $\mathrm{OH}^{-}$demand for full nitrification, which was estimated based on the TN concentration in the influent (Table S12). At the end of PN-I, after interrupting the influent flow for two days, the nitrate and TAN concentration remained unaffected (Section C4), confirming that the extent of nitrification was solely limited by the lack of alkalinity and not by a too slow nitrification rate (i.e., TAN accumulates when the nitrification rate is lower than the $\mathrm{N}$ loading rate).

In an attempt to increase the $\mathrm{NO}_{3}{ }^{-}-\mathrm{N} / \mathrm{TAN}$ ratio, influent with a higher alkalinity was fed to the reactor in phase PN-III. The influent was alkalinized with $\mathrm{NaOH}$ instead of an electrochemical cell in order to define the exact amount of $\mathrm{OH}^{-}$added to the urine. The latter is difficult to determine in electrochemically alkalinized urine, since the coulombic efficiency might drop at high $\mathrm{pH}(>12)$ due to $\mathrm{OH}^{-}$migration from the cathode to the middle compartment. Prior to $\mathrm{PN}-\mathrm{III}$, the bioreactor was conditioned with $\mathrm{NaOH}$-alkalinized influent $\left(22 \mathrm{mmol} \mathrm{OH}^{-} \mathrm{L}^{-1}\right.$ to obtain the same influent $\mathrm{pH}$ of 11.8 \pm 0.3 as in $\mathrm{PN}-\mathrm{I})$, resulting in a similar $\mathrm{NO}_{3}{ }^{-} \mathrm{N} / \mathrm{TAN}$ ratio $(60: 40)$ as in phase $\mathrm{PN}-\mathrm{I}$ on electrochemically alkalinized urine (Figure S12). After increasing the $\mathrm{OH}^{-}$content of the influent to $66 \mathrm{mmol} \mathrm{OH}^{-} \mathrm{L}^{-1}$ ( $\mathrm{pH}$ of $12.8 \pm 0.2$ ), the $\mathrm{NO}_{3}{ }^{-}-\mathrm{N} / \mathrm{TAN}$ ratio increased to $73: 27$ in phase PN-IIla. In phase PN-IIIb, the $\mathrm{NO}_{3}{ }^{-}-\mathrm{N} / T A N$ ratio further increased to $93: 7$, because of the lower $\mathrm{N}$ concentration in the influent (other batch of urine with only $668 \pm 90 \mathrm{mg} \mathrm{N} \mathrm{L}^{-1}$ compared to $1706 \pm 126 \mathrm{mg} \mathrm{N} \mathrm{L}^{-1}$ in PN-IIla) and, hence, a lower $\mathrm{OH}^{-}$demand. Similar to $\mathrm{PN}-\mathrm{I}$, the increased extent of nitrification in response to the increased influent alkalinity throughout operation on $\mathrm{NaOH}$-alkalinized urine was in line with the interpolated values (Table S12). Partial nitrification (TAN accumulation) was presumably caused by $\mathrm{NH}_{3}$ limitation and direct $\mathrm{pH}$ inhibition effects (e.g., a low reactor $\mathrm{pH}$ decreases the intracellular $\mathrm{pH}$, which affects the enzyme activity, protein and DNA stability and ATP generation). ${ }^{7}$

Over the course of 130 days, the partial nitrification reactor was stably operated at a $N$ and COD loading rate of $103 \mathrm{mg} \mathrm{N} \mathrm{L}^{-1} \mathrm{~d}^{-1}$ (PN-IIlb) - $250 \mathrm{mg} \mathrm{N} \mathrm{L}^{-1} \mathrm{~d}^{-1}$ (PN-I, PN-II, PN-IIla) and $132 \mathrm{mg} \mathrm{COD}$

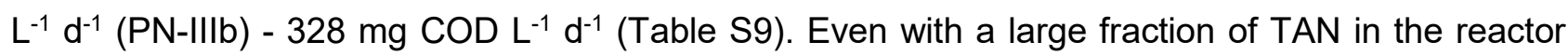
liquid (up to $621 \mathrm{mg} \mathrm{N} \mathrm{L}^{-1}$ ), free ammonia (FA) inhibition was avoided because of the low $\mathrm{pH}$ (less than $0.3 \%$ of TAN is present as $\mathrm{FA}$ at $\mathrm{pH} 6.7$ ). The nitrite concentration stayed below $15 \mathrm{mg} \mathrm{N} \mathrm{L}^{-1}$. 
The TN concentration in the effluent equalled the sum of the $\mathrm{TAN}$ and $\mathrm{NO}_{3}{ }^{-}-\mathrm{N}$ concentration in the effluent and corresponded to the TN concentration in the influent, indicating that all urea was hydrolyzed and no nitrogen was lost through denitrification or ammonia stripping (Figure S12). After switching to $\mathrm{NaOH}$-alkalinized urine, the sodium concentration increased threefold, increasing the electrical conductivity from $\sim 10 \mathrm{mS} \mathrm{cm}^{-1}$ (PN-I) to $\sim 15 \mathrm{mS} \mathrm{cm}^{-1}$ (PN-IIla) (Table S11).

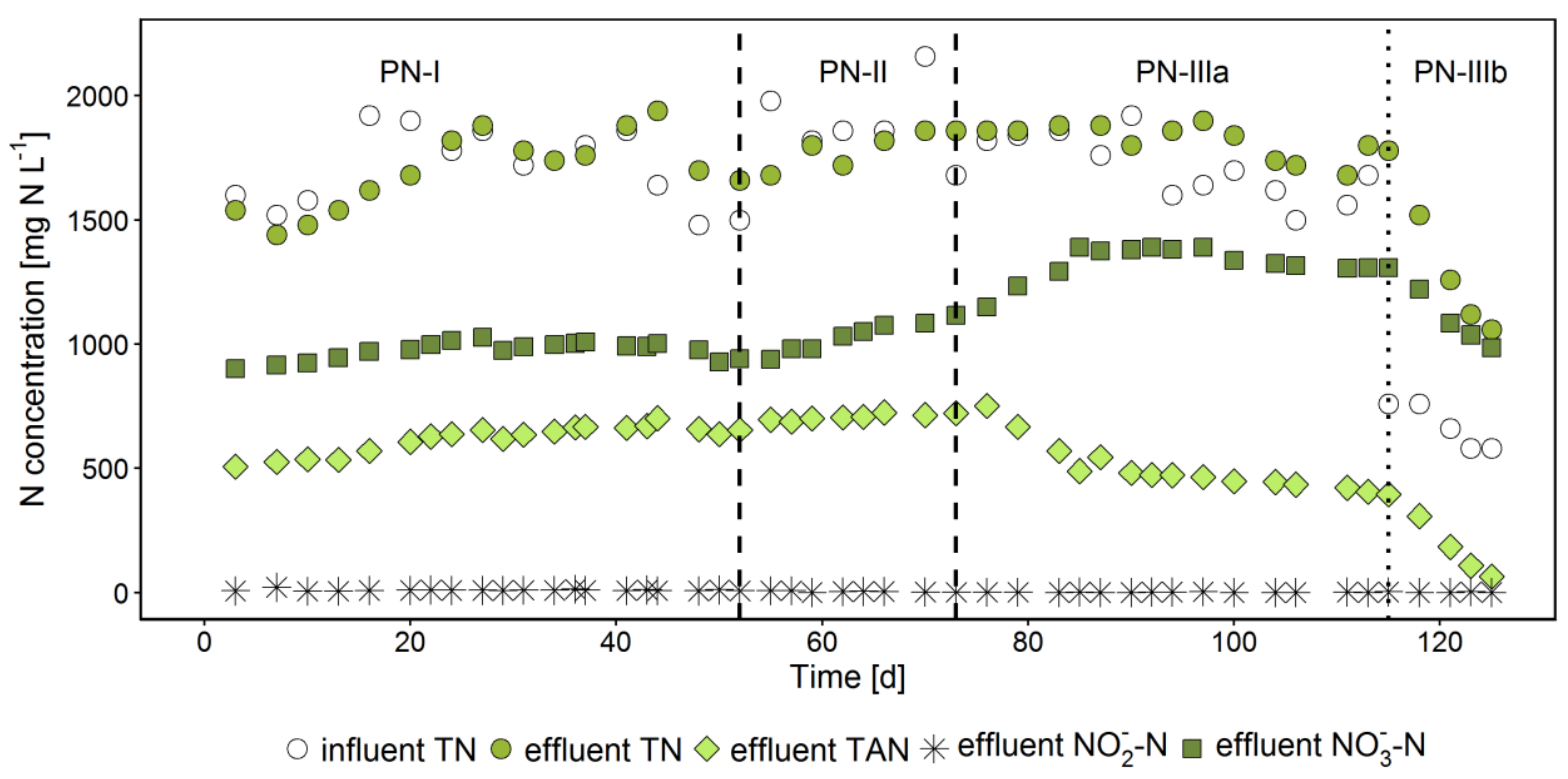

Figure S12. Total nitrogen (TN) concentration in the influent and TN, total ammonia nitrogen (TAN), nitrite and nitrate concentration in the effluent of the partial nitrification reactor. The influent and effluent composition is given in Figure S11 and Tables S10-S11. 
The combination of urea hydrolysis and nitrification results in a net acidification in a urine nitrification bioreactor. If all urea is hydrolyzed, about $50 \%$ of the nitrogen can be nitrified to nitrate (producing 2 $\mathrm{mol} \mathrm{H} / \mathrm{mol} \mathrm{N}$ nitrified).

$\mathrm{CO}\left(\mathrm{NH}_{2}\right)_{2}+4 \mathrm{O}_{2} \rightarrow 2 \mathrm{NO}_{3}^{-}+\mathrm{CO}_{2}+\mathrm{H}_{2} \mathrm{O}+2 \mathrm{H}^{+}$

Table S12. Estimated hydroxide demand for full nitrification and theoretical extent of nitrification (effluent $\mathrm{NO}_{3}{ }^{-}-\mathrm{N} / \mathrm{TN}$ ). The hydroxide demand for full nitrification was estimated based on the average total nitrogen (TN) concentration in the influent, assuming that $1 \mathrm{~mol} \mathrm{OH}^{-} \mathrm{mol}^{-1} \mathrm{~N}$ is required to obtain full nitrification. The theoretical nitrification percentage was estimated by interpolation. For example, in $\mathrm{PN}-\mathrm{I}$, an estimated $122 \mathrm{mmol} \mathrm{OH}^{-}$is required to obtain full nitrification (effluent $\mathrm{NO}_{3}{ }^{-}-\mathrm{N} / \mathrm{TN}=100$ ). Without any hydroxide addition, an effluent $\mathrm{NO}_{3}{ }^{-}-\mathrm{N} / \mathrm{TN}$ of $50 \%$ would be obtained. Hence, with $29 \mathrm{mmol} \mathrm{OH}^{-} \mathrm{L}^{-1}$, the effluent $\mathrm{NO}_{3}{ }^{-} \mathrm{N} / \mathrm{TN}$ is estimated at $62 \%$.

\begin{tabular}{|c|c|c|c|c|c|}
\hline & & PN-I & PN-II & PN-Illa & PN-IIIb \\
\hline average influent TN concentration & [mg N L-1] & 1710 & 1863 & 1706 & 668 \\
\hline $\begin{array}{l}\mathrm{OH}^{-} \text {demand for full nitrification } \\
\left(\mathrm{NO}_{3}{ }^{-}-\mathrm{N} / \mathrm{TAN} \text { of } 100: 0\right)\end{array}$ & {$\left[\mathrm{mmol} \mathrm{OH} \mathrm{L}^{-1}\right]$} & 122 & 133 & 122 & 48 \\
\hline $\mathrm{OH}^{-}$addition for stabilization & {$\left[\mathrm{mmol} \mathrm{OH} \mathrm{L}^{-1}\right]$} & 29 & 22 & 66 & 66 \\
\hline $\begin{array}{l}\text { theoretical nitrification percentage } \\
\text { (effluent } \mathrm{NO}_{3}-\mathrm{N} / \mathrm{TN} \text { ) }\end{array}$ & [\%] & 62 & 58 & 75 & $>100$ \\
\hline $\begin{array}{l}\text { nitrification percentage (effluent } \\
\mathrm{NO}_{3}{ }^{-}-\mathrm{N} / \mathrm{TN} \text { ) obtained in reactor }\end{array}$ & [\%] & $60: 40$ & $60: 40$ & $73: 27$ & $93: 7^{\mathrm{a}}$ \\
\hline
\end{tabular}




\section{C4. Nitrification activity test}

On day 50-51, the influent flow was stopped to examine if the $\mathrm{NO}_{3}-\mathrm{N} / \mathrm{TAN}$ ratio was limited by a too slow nitrification rate. The TAN and $\mathrm{NO}_{3}{ }^{-}-\mathrm{N}$ concentrations were followed over time (Figure S13).

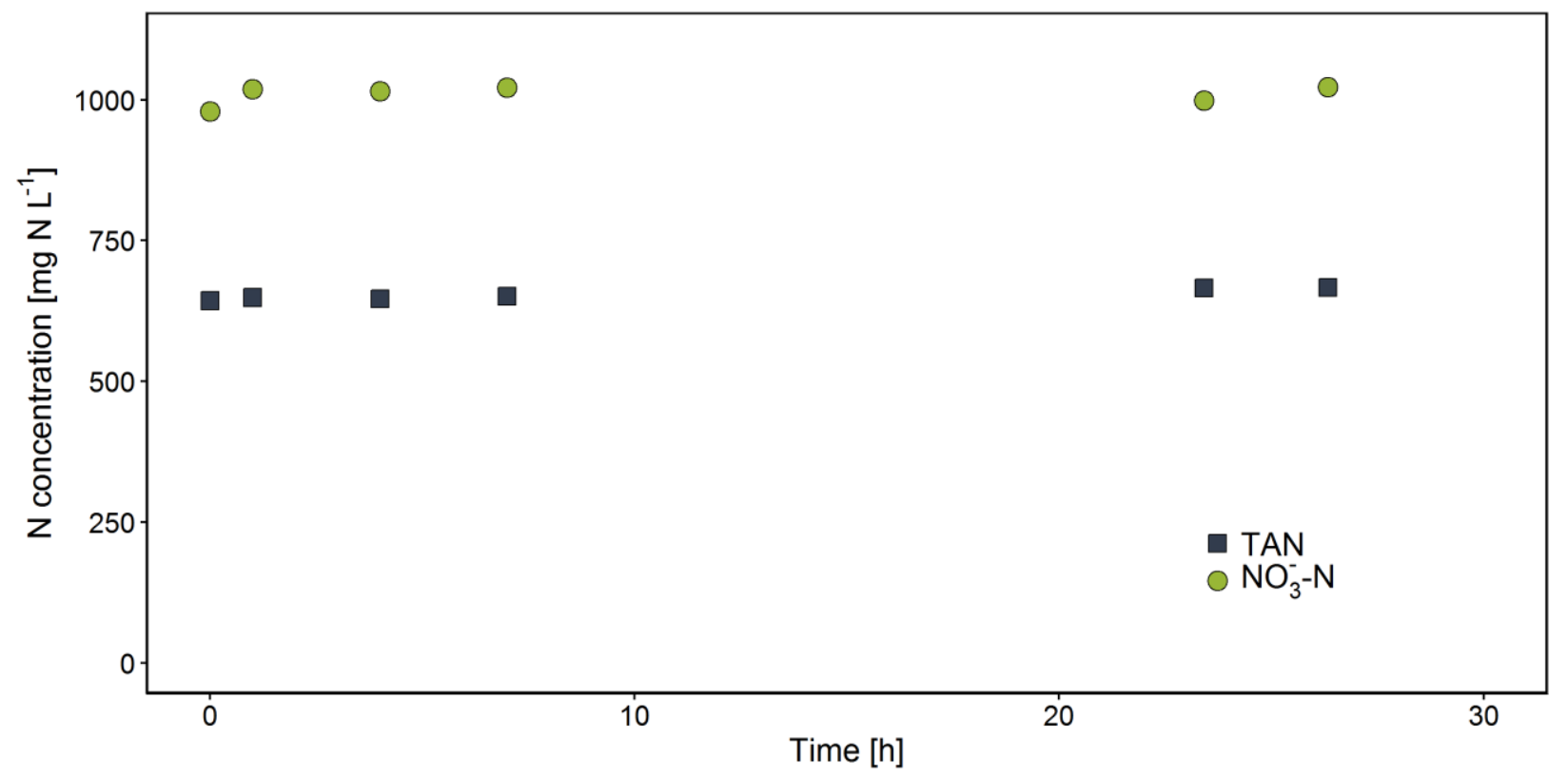

Figure S13. Total ammonia nitrogen (TAN) and nitrate concentration over time during the nitrification activity test. The influent flow was stopped at time 0 . 


\section{Full nitrification with $\mathrm{NaOH}$ addition}

\section{D1. Materials and methods}

\section{D1.1. Experimental setup}

The MBBR used for full nitrification with $\mathrm{NaOH}$ addition was similar to the MBBR used for partial nitrification and full nitrification with electrochemical hydroxide addition.

$\mathrm{A} \mathrm{pH}$ probe (Consort, Belgium) was installed in the reactor which was connected to a $\mathrm{pH}$ controller (VP-PRO-PH/RX, Verder, Belgium) to control the $\mathrm{pH}$ at 6.7 or 7.5 by adding 1 or $1.5 \mathrm{M} \mathrm{NaOH}$. This reactor served as a 'control' to compare the $\mathrm{OH}^{-}$consumption and reactor salinity with the full nitrification reactor with electrochemical $\mathrm{OH}^{-}$addition.

\section{D1.2. Urine influent}

It was the aim to compare the difference in salinity resulting from base addition versus electrochemical $\mathrm{OH}^{-}$addition in the two-step urine stabilization process (alkalinization and subsequent nitrification). Therefore, the influent of the MBBR with $\mathrm{NaOH}$ addition was stabilized using $2 \mathrm{M} \mathrm{NaOH}$ whereas the influent of the MBBR with electrochemical $\mathrm{OH}^{-}$addition was stabilized with an electrochemical cell according to De Paepe et al. (2020) ${ }^{2}$ (Section A4). 


\section{D2. Influent and effluent composition}

Table S13. Nitrogen and COD load, and composition of the influent and effluent of the full nitrification reactor with $\mathrm{NaOH}$ addition. $Q_{\text {in }}=$ influent flow rate, $Q_{\text {out }}=$ effluent flow rate.

\begin{tabular}{|c|c|c|c|c|}
\hline \multicolumn{2}{|l|}{ day } & \multicolumn{3}{|c|}{$1-51$} \\
\hline HRT in reactor & [d] & 6.1 & \pm & 0.2 \\
\hline duration & [number of HRT] & \multicolumn{3}{|c|}{8.4} \\
\hline$Q_{\text {in }}$ & {$\left[\mathrm{L} \mathrm{d}^{-1}\right]$} & 489 & \pm & 15 \\
\hline Qout & {$\left[\mathrm{L} \mathrm{d}^{-1}\right]$} & 539 & \pm & 19 \\
\hline $\mathrm{N}$ load & {$\left[\mathrm{mg} \mathrm{N} \mathrm{d}^{-1}\right]$} & 939 & \pm & 162 \\
\hline $\mathrm{N}$ loading rate & {$\left[\mathrm{mg} \mathrm{N} \mathrm{L}^{-1} \mathrm{~d}^{-1}\right]$} & 289 & \pm & 33 \\
\hline COD load & {$\left[\mathrm{mg} \mathrm{COD} \mathrm{d}{ }^{-1}\right]$} & 948 & \pm & 92 \\
\hline COD loading rate & {$\left[\mathrm{mg} \mathrm{COD} \mathrm{L} \mathrm{L}^{-1} \mathrm{~d}^{-1}\right]$} & 292 & \pm & 28 \\
\hline \multicolumn{5}{|l|}{ Influent composition } \\
\hline $\mathrm{pH}$ & & 11.3 & \pm & 0.4 \\
\hline electrical conductivity & {$\left[\mathrm{mS} \mathrm{cm}^{-1}\right]$} & 6.6 & \pm & 0.7 \\
\hline suspended COD & {$[\mathrm{mg} \mathrm{COD} \mathrm{L-1}]$} & 1929 & \pm & 152 \\
\hline total nitrogen & {$\left[\mathrm{mg} \mathrm{N} \mathrm{L}^{-1}\right]$} & 1966 & \pm & 184 \\
\hline total ammonia nitrogen & {$\left[\mathrm{mg} \mathrm{N} \mathrm{L}^{-1}\right]$} & 73 & \pm & 7 \\
\hline nitrite & {$\left[\mathrm{mg} \mathrm{N} \mathrm{L}^{-1}\right]$} & 0 & \pm & 0 \\
\hline nitrate & [mg N L-1] & 6 & \pm & 1 \\
\hline phosphate & {$\left[\mathrm{mg} \mathrm{L}^{-1}\right]$} & 119 & \pm & 19 \\
\hline sulfate & {$\left[\mathrm{mg} \mathrm{L}^{-1}\right]$} & 302 & \pm & 33 \\
\hline chloride & {$\left[\mathrm{mg} \mathrm{L}^{-1}\right]$} & 1164 & \pm & 130 \\
\hline sodium & {$\left[\mathrm{mg} \mathrm{L}^{-1}\right]$} & 1159 & \pm & 93 \\
\hline potassium & {$\left[\mathrm{mg} \mathrm{L}^{-1}\right]$} & 659 & \pm & 33 \\
\hline \multicolumn{5}{|l|}{ Effluent composition } \\
\hline $\mathrm{pH}$ & & 8 & \pm & 0.5 \\
\hline electrical conductivity & {$[\mathrm{mS} \mathrm{cm}-1]$} & 15.7 & \pm & 1.6 \\
\hline suspended COD & {$[\mathrm{mg} \mathrm{COD} \mathrm{L-1}]$} & 345 & \pm & 71 \\
\hline total nitrogen & {$\left[\mathrm{mg} \mathrm{N} \mathrm{L}^{-1}\right]$} & 1659 & \pm & 197 \\
\hline total ammonia nitrogen & {$\left[\mathrm{mg} \mathrm{N} \mathrm{L}^{-1}\right]$} & 56 & \pm & 82 \\
\hline nitrite & {$\left[\mathrm{mg} \mathrm{N} \mathrm{L}^{-1}\right]$} & 16 & \pm & 35 \\
\hline nitrate & {$\left[\mathrm{mg} \mathrm{N} \mathrm{L}^{-1}\right]$} & 1484 & \pm & 279 \\
\hline phosphate & {$\left[\mathrm{mg} \mathrm{L}^{-1}\right]$} & 134 & \pm & 47 \\
\hline sulfate & {$\left[\mathrm{mg} \mathrm{L}^{-1}\right]$} & 378 & \pm & 88 \\
\hline chloride & {$\left[\mathrm{mg} \mathrm{L}^{-1}\right]$} & 1076 & \pm & 241 \\
\hline sodium & {$\left[\mathrm{mg} \mathrm{L}^{-1}\right]$} & 2960 & \pm & 532 \\
\hline potassium & {$\left[\mathrm{mg} \mathrm{L}^{-1}\right]$} & 613 & \pm & 113 \\
\hline
\end{tabular}




\section{D3. Nitrification performance}

Full nitrification was obtained in the first 51 days at a $\mathrm{pH}$ set point of 7.5 and an average $\mathrm{N}$ loading rate of $289 \mathrm{mg} \mathrm{N} \mathrm{L}^{-1} \mathrm{~d}^{-1}$, apart from some TAN and $\mathrm{NO}_{2}^{-}-\mathrm{N}$ accumulation on day 23 (due to DO limitation caused by clogging of the aeration stones). The nitrate concentration in the effluent equalled the TN concentration in the effluent (indicating that all urea was converted into nitrate) and equalled the TN concentration in the influent (indicating that no nitrogen was lost through denitrification or ammonia stripping) (Figure S14). About $20-25 \mathrm{mmol} \mathrm{OH}^{-} \mathrm{L}^{-1}$ was added to increase the $\mathrm{pH}$ to 12 before storage and $106 \mathrm{mmol} \mathrm{OH}^{-} \mathrm{L}^{-1}$ was added by the $\mathrm{pH}$ controller in the bioreactor. The total amount of hydroxide added $\left(\sim 130 \mathrm{mmol} \mathrm{OH}^{-} \mathrm{L}^{-1}\right)$ corresponded well to the estimated hydroxide demand for full nitrification $\left(138 \mathrm{mmol} \mathrm{OH}^{-} \mathrm{L}^{-1}\right)$.

After lowering the $\mathrm{pH}$ set point to 6.7, TAN and $\mathrm{NO}_{2}-\mathrm{N}$ started to accumulate. Due to the decreased nitrification activity (Section D4), the loading was reduced from day 59 onwards. Since the nitrification activity could not be restored (increasing TAN and $\mathrm{NO}_{2}^{-}-\mathrm{N}$ concentrations), the $\mathrm{pH}$ set point was again increased to 7.5 on day 100 and the bioreactor was emptied and filled with diluted effluent from the electrochemically controlled full nitrification reactor (decreasing the TAN, $\mathrm{NO}_{2}{ }^{-}-\mathrm{N}^{-}$and $\mathrm{NO}_{3}{ }^{-}$ $-\mathrm{N}$ concentrations). Next, the loading was gradually increased. The TAN and $\mathrm{NO}_{2}-\mathrm{N}$ concentrations remained below $10 \mathrm{mg} \mathrm{N} \mathrm{L}^{-1}$, and the $\mathrm{NO}_{3}{ }^{-}-\mathrm{N}$ concentration coincided with the TN concentration in the effluent. On day 112 the $\mathrm{pH}$ set point was again lowered to 6.7 and the loading was gradually increased to $\sim 300 \mathrm{mg} \mathrm{N} \mathrm{L}^{-1} \mathrm{~d}^{-1}$. The $\mathrm{NO}_{3}{ }^{-}-\mathrm{N}$ and $\mathrm{TN}$ concentration gradually increased and equalled the influent TN concentration at the end. 


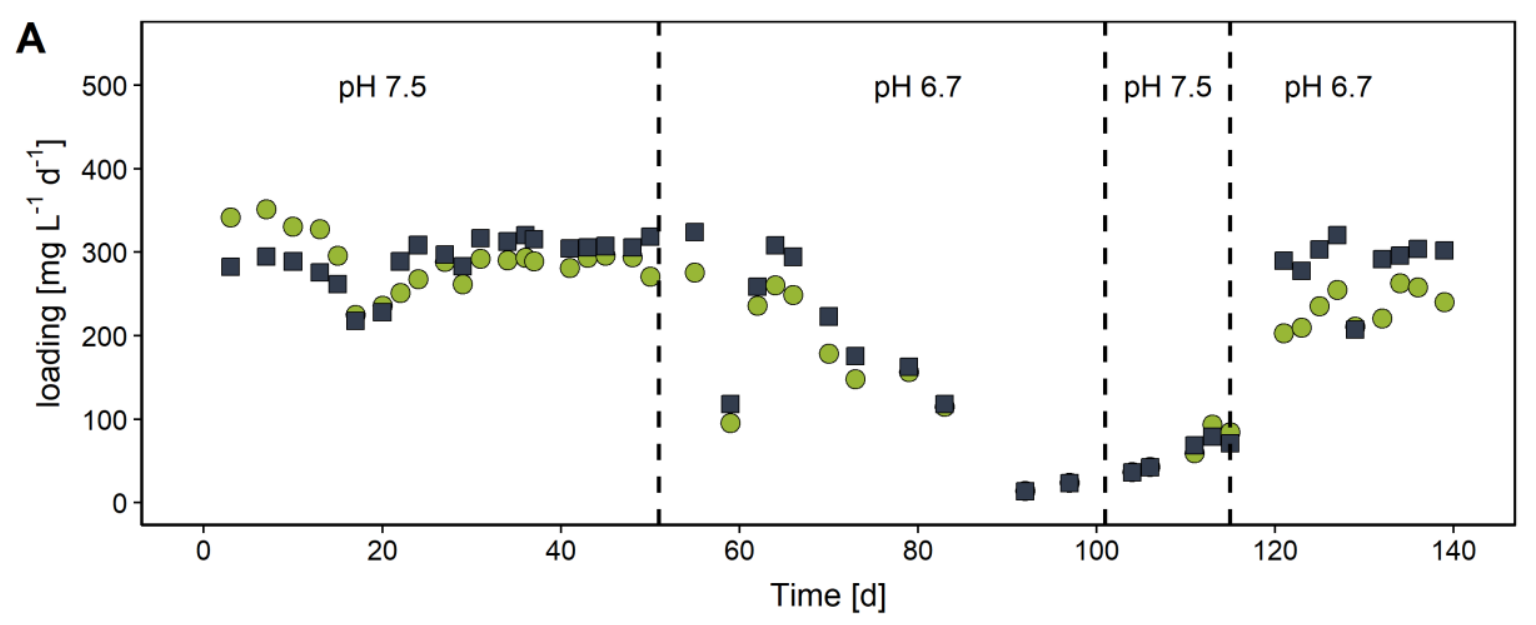

- COD loading $\bigcirc \mathrm{N}$ loading
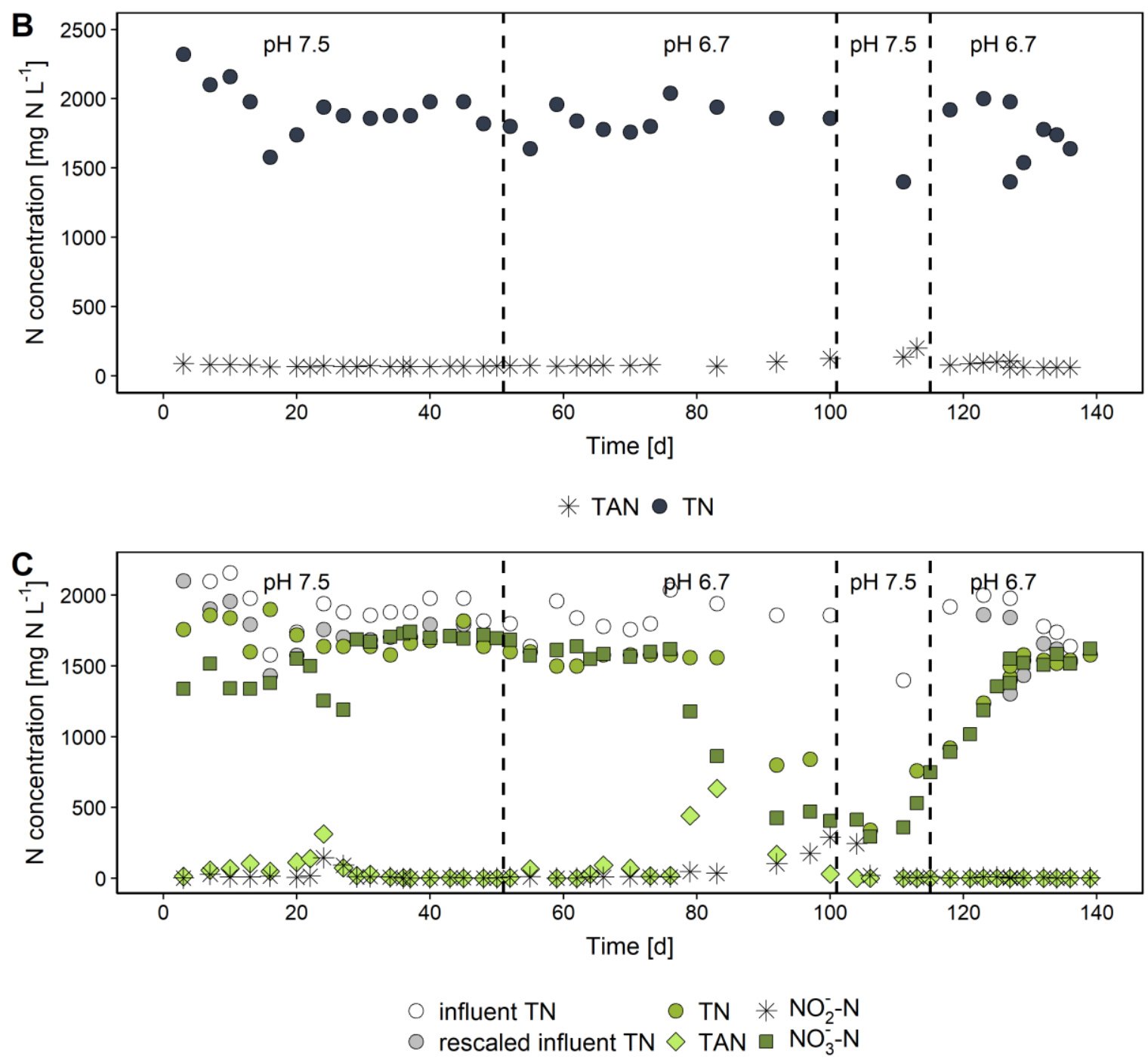

Figure S14. Full nitrification reactor with $\mathrm{NaOH}$ addition. A: Nitrogen and COD loading; B: Total nitrogen (TN) and total ammonia nitrogen (TAN) concentration in the influent; C: TN concentration in the influent, rescaled TN concentration in the influent (to account for the difference in influent and effluent volume due to the $\mathrm{NaOH}$ addition), TN, TAN, nitrite and nitrate concentration in the effluent. 


\section{D4. Nitrification activity test}

On day 48-50, before shifting to a lower $\mathrm{pH}$ set point, the maximum nitrification rate was determined in a batch experiment. The influent was disconnected and the bioreactor was spiked with $150 \mathrm{~mL}$ of urine. The TAN and nitrite concentrations were followed up over time. The nitrification rate was derived from the slope of the TAN concentration as a function of time (between peak and $0 \mathrm{mg} \mathrm{N} \mathrm{L}^{-}$ $\left.{ }^{1}\right)$. The same experiment was repeated on day 52,55 and 57 at a $\mathrm{pH}$ set point of 6.5. The nitrification rate at $\mathrm{pH} 6.5$ was significantly lower $(\mathrm{p}=0.0121)$ compared to $\mathrm{pH} 7.5$. This caused TAN and $\mathrm{NO}_{2}{ }^{-}-\mathrm{N}$ accumulation in the bioreactor after shifting the $\mathrm{pH}$ set point, since the nitrogen loading rate was higher than the nitrification rate.

A

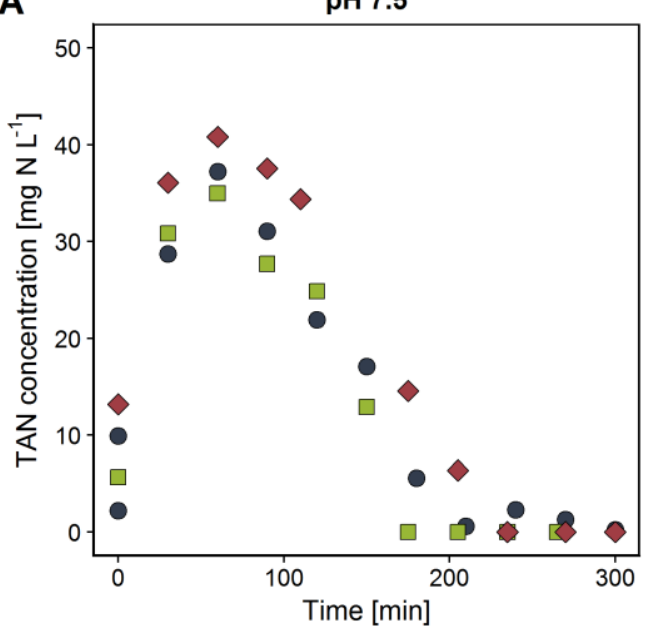

C

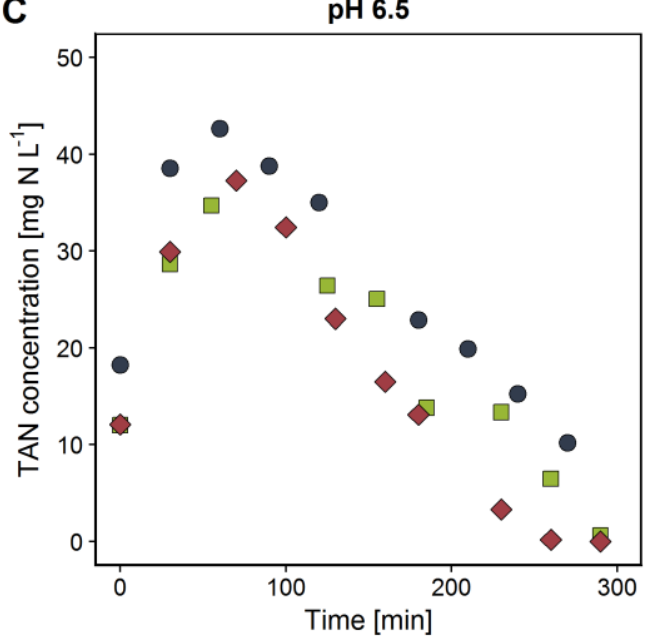

B

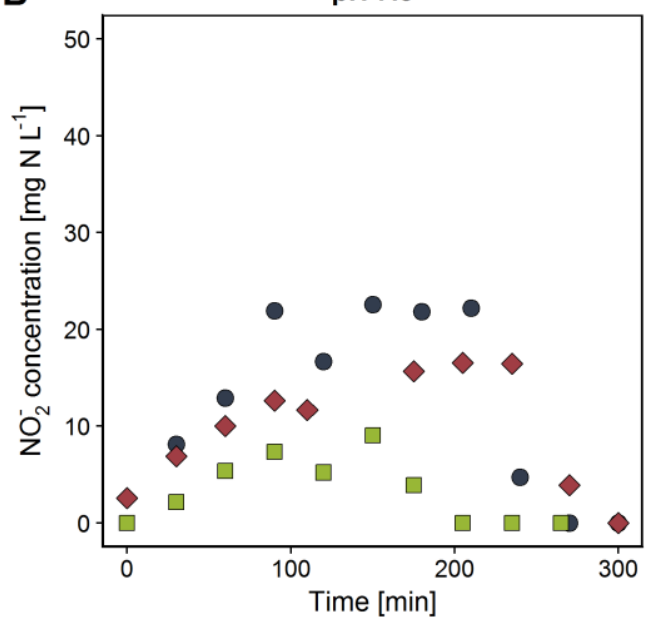

D

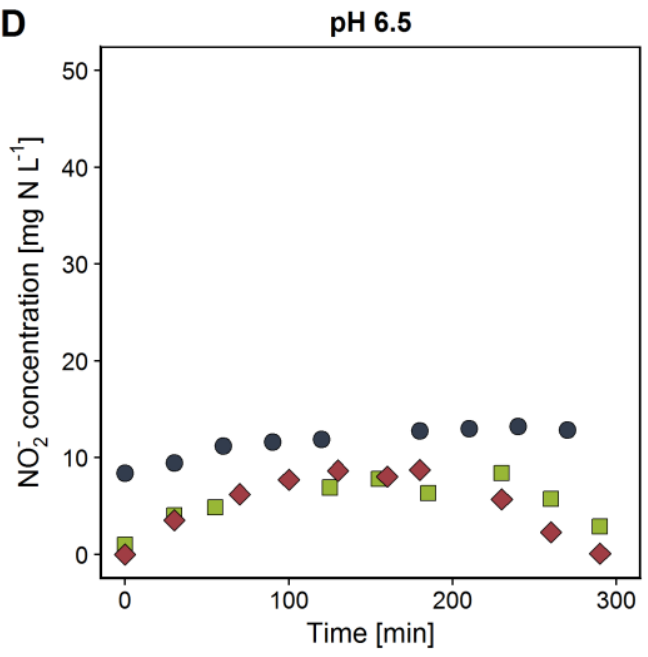

Figure S15. Total ammonia nitrogen (TAN) and nitrite concentration over time. A spike of urine was given at time 0 . During the first 50 minutes, TAN increased because of ureolysis. Subsequently, TAN decreased due to nitritation. 
Table S14. Nitrification rate at pH 7.5 and 6.7. The nitrification rate was derived from the slope of the TAN concentration as a function of time (between peak and $0 \mathrm{mg} \mathrm{N} \mathrm{L}^{-1}$ ). AV=average; $\mathrm{SD}=$ standard deviation $(n=3)$.

\begin{tabular}{lcccc}
\hline & \multicolumn{2}{c}{$\mathbf{p H ~ 7 . 5}$} & \multicolumn{2}{c}{$\mathbf{p H ~ 6 . 7}$} \\
& rate & $\mathrm{R}^{2}$ & rate & $\mathrm{R}^{2}$ \\
\hline 1 & -0.25 & 0.99 & -0.15 & 1.00 \\
2 & -0.29 & 0.93 & -0.14 & 0.96 \\
3 & -0.25 & 0.99 & -0.20 & 0.99 \\
$\mathrm{AV}\left[\mathrm{mg} \mathrm{N} \mathrm{L}^{-1} \mathrm{~min}^{-1}\right]$ & -0.26 & & -0.167 & \\
$\mathrm{SD}$ & 0.0223 & & 0.0313 & \\
\hline
\end{tabular}




\section{E. Comparison}

Table S15. Nitrogen over sodium ratio and nitrogen over chloride ratio in the influent and effluent of the reactor with partial nitrification, full nitrification with $\mathrm{NaOH}$ addition and full nitrification with electrochemical hydroxide addition.

\begin{tabular}{|c|c|c|c|c|c|c|}
\hline & \multicolumn{3}{|c|}{$\mathrm{N} / \mathrm{Na}$ ratio $(\mathrm{mol} / \mathrm{mol})$} & \multicolumn{3}{|c|}{$\mathrm{N} / \mathrm{Cl}(\mathrm{mol} / \mathrm{mol})$} \\
\hline & influent & \multicolumn{2}{|c|}{ bioreactor } & influent & \multicolumn{2}{|c|}{ bioreactor } \\
\hline \multicolumn{7}{|c|}{ partial nitrification reactor without $\mathrm{pH}$ control } \\
\hline PN-I & 4.8 & \multicolumn{2}{|c|}{4.7} & 8.5 & \multicolumn{2}{|c|}{8.0} \\
\hline PN-II & 2.7 & \multicolumn{2}{|c|}{3.0} & 4.1 & \multicolumn{2}{|c|}{4.5} \\
\hline PN-IIla & 1.5 & \multicolumn{2}{|c|}{1.6} & 3.8 & \multicolumn{2}{|c|}{3.9} \\
\hline PN-IIIb & 0.6 & \multicolumn{2}{|c|}{1.0} & 3.2 & \multicolumn{2}{|c|}{4.0} \\
\hline \multicolumn{7}{|c|}{ full nitrification reactor with $\mathrm{NaOH}$ control } \\
\hline $\mathrm{pH} 7.6$ & 2.8 & \multicolumn{2}{|c|}{0.9} & 4.3 & \multicolumn{2}{|c|}{3.9} \\
\hline $\mathrm{pH} 6.7$ & 2.8 & \multicolumn{2}{|c|}{0.9} & 3.9 & \multicolumn{2}{|c|}{3.8} \\
\hline \multicolumn{7}{|c|}{ full nitrification reactor with electrochemical pH control } \\
\hline & influent & bioreactor & $\begin{array}{c}\text { middle } \\
\text { compartment }\end{array}$ & influent & bioreactor & $\begin{array}{c}\text { middle } \\
\text { compartment }\end{array}$ \\
\hline $\begin{array}{l}\text { Configuration 1, } \\
\mathrm{pH} 7.5\end{array}$ & 4.5 & 1.1 & 4.3 & 6.9 & 4.6 & 6.1 \\
\hline \multirow[t]{2}{*}{$\begin{array}{l}\text { Configuration 1, } \\
\mathrm{pH} 6.5\end{array}$} & 4.2 & 1.3 & 4.4 & 6.3 & 4.7 & 6.2 \\
\hline & influent & bioreactor & $\begin{array}{c}\text { middle } \\
\text { compartment }\end{array}$ & influent & bioreactor & $\begin{array}{c}\text { middle } \\
\text { compartment }\end{array}$ \\
\hline $\begin{array}{l}\text { Configuration } 2 \text {, } \\
\text { factor } 2\end{array}$ & 4.5 & 1.2 & 3.0 & 6.8 & 4.7 & 6.2 \\
\hline \multirow[t]{2}{*}{$\begin{array}{l}\text { Configuration } 2 \text {, } \\
\text { factor } 5\end{array}$} & 4.2 & 1.1 & 31.1 & 6.1 & 5.0 & 6.0 \\
\hline & influent & $\begin{array}{c}\text { anodic } \\
\text { compartment }\end{array}$ & $\begin{array}{c}\text { middle } \\
\text { compartment }\end{array}$ & influent & $\begin{array}{c}\text { anodic } \\
\text { compartment }\end{array}$ & $\begin{array}{c}\text { middle } \\
\text { compartment }\end{array}$ \\
\hline $\begin{array}{l}\text { Configuration } 3 \text {, } \\
\text { factor } 2\end{array}$ & 4.9 & 2.8 & 4.5 & 7.4 & 5.8 & 6.9 \\
\hline $\begin{array}{l}\text { Configuration } 3 \text {, } \\
\text { factor } 5\end{array}$ & 5.4 & 3.4 & 4.9 & 8.0 & 6.4 & 6.8 \\
\hline
\end{tabular}




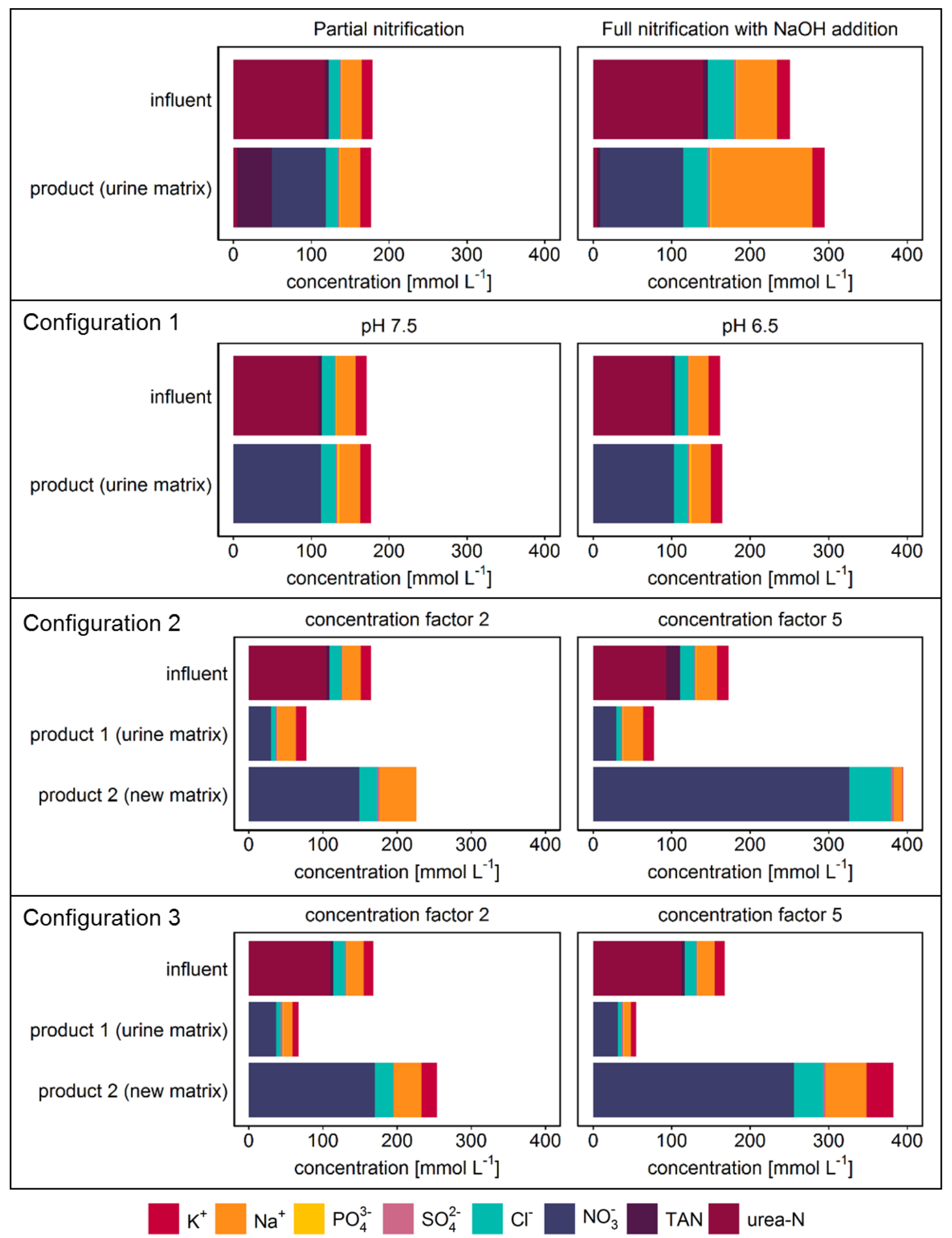

Figure S16. Composition of the influent and end product(s) of partial nitrification, full nitrification with $\mathrm{NaOH}$ addition and full nitrification with electrochemical hydroxide addition (configuration 1-3). 
Table S16. Cost comparison.

\begin{tabular}{lll}
\hline NaOH addition & & \\
\hline cost of $\mathrm{NaOH}$ & 250 & $€ \mathrm{ton}^{-1} \mathrm{NaOH}^{8}$ \\
& 0.01 & $€ \mathrm{~mol}^{-1} \mathrm{NaOH}$ \\
$\mathrm{NaOH}$ consumption & 106 & $\mathrm{mmol} \mathrm{OH}^{-1}$ (Section D3) \\
& 318 & $\mathrm{~mol} \mathrm{NaOH} \mathrm{m}^{-3}$ urine \\
cost of $\mathrm{NaOH}$ dosing & 3.2 & $€ \mathrm{~m}^{-3}$ urine \\
\hline Electrochemical hydroxide addition & & \\
\hline electricity cost (Belgium, 20-499 MWh/year) ${ }^{a}$ & 0.15 & $€ \mathrm{kWh}^{-1}$ \\
energy consumption for pH control (power supply) & $25-60$ & $\mathrm{kWh} \mathrm{m}^{-3}$ urine \\
cost for pH control & $3.8-9.0$ & $€ \mathrm{~m}^{-3}$ urine \\
\hline${ }^{a}$ https://www.unizo.be/sites/default/files/190827 vlaamseelektriciteitsnorm $0 . p d f$ &
\end{tabular}




\section{References}

1. De Paepe, J.; Lindeboom, R. E. F.; Vanoppen, M.; De Paepe, K.; Demey, D.; Coessens, W.; Lamaze, B.; Verliefde, A. R. D.; Clauwaert, P.; Vlaeminck, S. E., Refinery and concentration of nutrients from urine with electrodialysis enabled by upstream precipitation and nitrification. Water Res. 2018, 144, 76-86.

2. De Paepe, J.; De Pryck, L.; Verliefde, A. R. D.; Rabaey, K.; Clauwaert, P., Electrochemically Induced Precipitation Enables Fresh Urine Stabilization and Facilitates Source Separation. Environ. Sci. Technol. 2020, 54, (6), 3618-3627.

3. Udert, K. M.; Wachter, M., Complete nutrient recovery from source-separated urine by nitrification and distillation. Water Res. 2012, 46, (2), 453-464.

4. Bischel, H. N.; Schertenleib, A.; Fumasoli, A.; Udert, K. M.; Kohn, T., Inactivation kinetics and mechanisms of viral and bacterial pathogen surrogates during urine nitrification. Environ. Sci.-Wat. Res. Technol. 2015, 1, (1), 65-76.

5. Udert, K. M.; Fux, C.; Munster, M.; Larsen, T. A.; Siegrist, H.; Gujer, W., Nitrification and autotrophic denitrification of source-separated urine. Water Sci. Technol. 2003, 48, (1), 119-130.

6. Feng, D. L.; Wu, Z. C.; Wang, D. H., Effects of N source and nitrification pretreatment on growth of Arthrospira platensis in human urine. J. Zhejiang Univ.-SCI A 2007, 8, (11), 1846-1852.

7. Fumasoli, A.; Bürgmann, H.; Weissbrodt, D. G.; Wells, G. F.; Beck, K.; Mohn, J.; Morgenroth, E.; Udert, K. M., Growth of Nitrosococcus-Related Ammonia Oxidizing Bacteria Coincides with Extremely Low pH Values in Wastewater with High Ammonia Content. Environ. Sci. Technol. 2017, 51, (12), 6857-6866. 8. Andersen, S. J.; Candry, P.; Basadre, T.; Khor, W. C.; Roume, H.; Hernandez-Sanabria, E.; Coma, M.; Rabaey, K., Electrolytic extraction drives volatile fatty acid chain elongation through lactic acid and replaces chemical pH control in thin stillage fermentation. Biotechnology for Biofuels 2015, 8, (1), 221. 